\title{
Implementation Of Automated Systems For Target Cost Management And Assessing Performance: A Case Study In A Global Automobile Component Company
}

\author{
Sung Jin Park, Sungshin Women's University, South Korea
}

Woo Jin Park, Yonsei University, South Korea

Sohee Woo, Woosong University, South Korea

\begin{abstract}
We examine the implementation of automated systems for target cost management and assessing firm performance in global automobile component company. After financial crisis, companies need to make strategic decisions as fast as possible. However, global companies are difficult to make fast decisions because of taking time for sorting the internal data through oversea companies. Also there are difficult to build systems of cost management and assessment of performance achievement. In this study, as we explain elaborately about the automatic process of cost management and assessment of performance achievement systems in global automobile component companies, we provide practical implications of this benchmark case for other companies' automated target cost management systems and assessing performance system's innovations.
\end{abstract}

Keywords: Target Costing; Automated Cost Management System; Assessment of Performance

\section{INTRODUCTION}

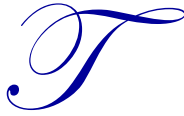

he diversification of customer requests and the intense competition triggered by the recent economic recession have raised the need for companies to cut back on costs and to develop high-quality products. The automobile industry, in particular, is in dire need of overseas market expansion and cost reduction for future growth. Furthermore, as processing precision has been improved by the automation of the manufacturing environment, companies face limitations in reducing processing costs and are thus in need of a more fundamental solution. In other words, it has become essential to plan and manage the production costs from the early planning stages, prior to product manufacturing. This is because $75 \sim 90 \%$ of the production costs for market surveys, research, design, prototype production, manufacturing, sales, and follow-up management are determined before production takes place (Blanchard, 1978; Berliner and Brimson, 1988; Cooper 1995; Foster and Sjoblom, 1996; Lee and Kim, 2003).

In this sense, in order to manage production costs efficiently, companies must implement a system to manage their costs from the early product planning or design stages, which are pre-manufacturing phases. Therefore, this study examines the efforts made by firms to cut back on costs in the pre-production stages - i.e. the planning, research \& development, and design stages. Along with JIT (just in time), target cost management is actually a business management technique typically adopted by Japanese firms. However, this method is not limited to Japanese companies but can be extensively applied to other countries as well. Because the reduction in processing costs has reached a limit due to the rapid automation of production processes from the late $20^{\text {th }}$ century, firms must cut back on costs in other areas, including the pre-production $\mathrm{R} \& \mathrm{D}$, design and planning stages, in order to achieve additional cost-cutting. In this regard, studies on the efficiency and quality improvement of production processes have been consistently carried out from an engineering perspective (Ibusuki and Kaminski 2007, Zengin and Ada 2010, Yazdifar and Askarany, 2012). 
However, companies facing fierce competition in today's global environment must do more than extend cost management to the pre-production R\&D, design and planning phases. Therefore, target cost management must be extended in a direction that facilitates customer satisfaction, market share acquisition, and profit creation by considering countless strategic variables including market trends, customer needs, and product quality from the product planning phase (Park and Bae 1999). In other words, companies now need real-time information to control the changing constraint conditions in a way that deviates from the conventional method of minimizing costs under given constraint conditions. Thus, it has become essential for firms to strengthen their management of the information related to external risk, such as the data provided by purchasing and sales departments, and that related to internal risk, such as the labor cost rate. Companies need an extended system that can re-alter the target function (production process) by changing the constraint conditions (internal/external risks). However, there are currently no studies including both the production and management viewpoints. Conducting such an extensive study therefore holds significance from both an academic and business perspective.

In accordance with the target cost system (Cooper and Slagmulder 2000) that calculates costs through a system input based on the price information determined by market consumers rather than the traditional price-setting method that views production costs as the output, this study selected the case of a company that constructed a target cost system for strategically controlling and managing the production costs of the whole company by conducting a sensitivity analysis through the calculation of the target profit rate of the purchasing and sales divisions. Based on information regarding the construction case, this study attempts to identify the milestones in the direction of strategic cost management and to point out several problems. It is expected to provide a basic framework of reference for companies hoping to create target cost management systems in the future.

The case study was conducted on A Company. This firm was chosen as it is a large company (approximately 3 billion dollar in sales) in the Korean automobile industry which has recently built a target cost management system. The company held public hearings and executive meetings in March 2013. During these, an agreement was reached to construct the system, which was in turn completed in July 2013.

Following the introduction, this paper goes on to examine the concept and characteristics of target cost management in Section 2, and reviews precedent studies related to the system in Section 3. Section 4 digs further into how the system was constructed by the company analyzed in this study. This includes a brief outline of the firm, the circumstances that led to the construction of the system, the main problems which arose in designing the system, and the solutions for these issues. Section 5 discusses the various problems that can be generated in the process of building automated systems for target cost management and assessing firm performance and finally, Section 6 summarizes the study and provides possible directions for future research.

\section{OUTLINE OF TARGET COSTS}

\subsection{Concept of Target Cost Management}

Target cost management is a representative pre-cost management method in relation to the target concept that spread quickly, mainly through the Japanese automobile, electric and machinery industries (e.g. Toyota, Nissan, Daihatsu, Toshiba), after the first oil shock. The main point of target cost management is to set the target costs before product planning, to design the product within the scope, to evaluate the results through cost estimation and to improve the costs if the target costs fall short of the results (Kato 1993; Yook 1994). The wide array of customer values found in today's market have reduced the lifecycles of products, magnifying the importance of developing new products and managing costs in the planning and design stages. As shown in Fig. 1, the relationship between the locked in cost and incurred cost in our increasingly automated manufacturing environment is concentrated at the production stage. However, as more than $70 \%$ of the production costs are decided in the preliminary stages, cost management is meaningless unless it is initiated prior to the production activities.

This realization led to the needs of a new cost management method that achieves cost reduction in the premanufacturing phases by tracking down the source of cost. Consequently, this has increased the importance of target cost management in the planning and developmental stages over mere cost improvement, which is the method of managing costs in the production stage. Besides, the shortened product lifecycles caused by the diversification of 
customer values further raise the importance of new product development and cost management in the planning and design stages.

On the other hand, the progresses in factory automation have reduced the importance of standard costing, which had conventionally been used by firms as a cost management method to control the efficiency of the production process. The role of standard costing as a means to enhance work efficiency was minimized as industrial robots replaced workers in the production process. In other words, as the focus of cost management has moved from higher workers' efficiency to the engineers who design the products and the production process, standard costing - which only managed the production process based on conventional scientific management techniques - was faced with limitations and replaced by new paradigms for cost reduction, including engineering cost design, value analysis, and value engineering.

Figure 1. The relationship between the locked in cost and incurred cost

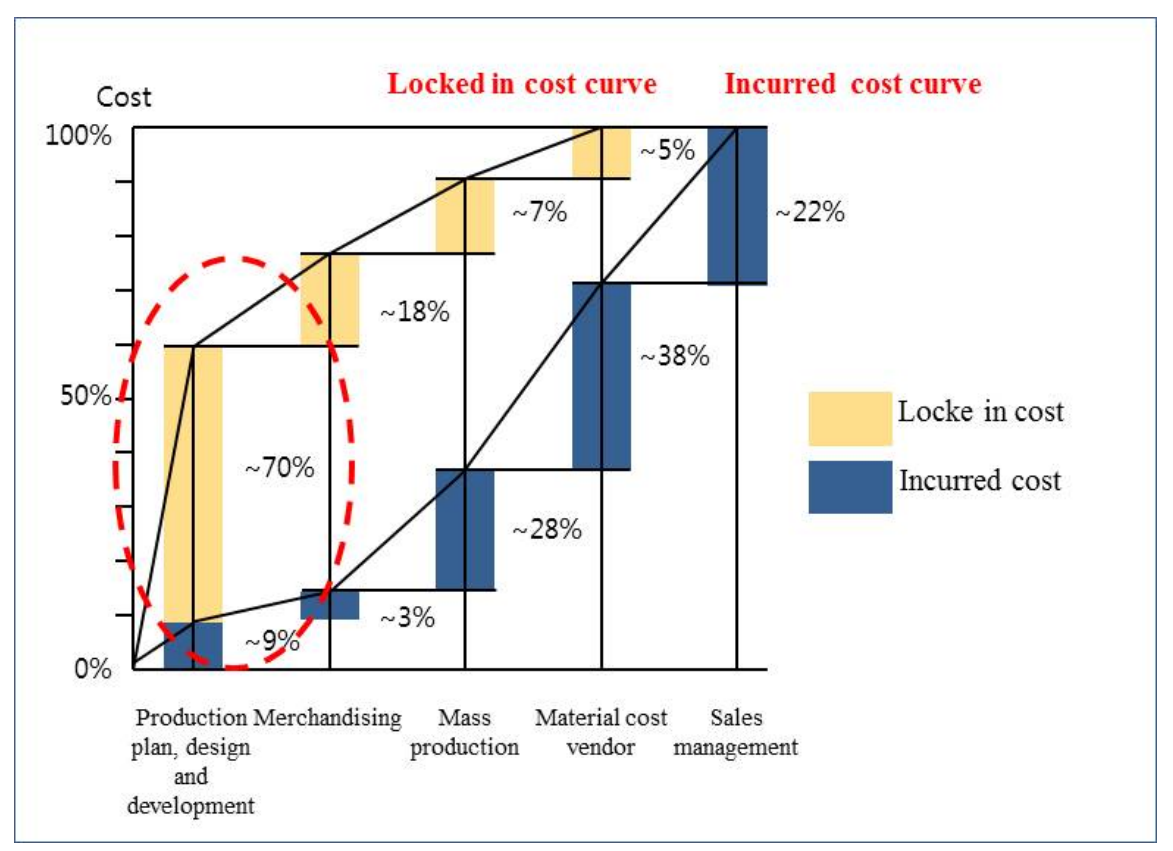

\subsection{Characteristics of Target Cost Management}

Although target cost management differs according to the development phase and corporate business type, its fundamental goal is to examine all cost-cutting possibilities from the source in order to achieve the target cost as planned. In other words, it is the process of making specific plans for a product that meets customer needs, deducting the target cost from the target profit of the new product, and calculating the actual cost to check whether the target cost has been achieved in the value engineering aspect. Value engineering is different from the traditional cost-control method based on standard costing in that it presents creative plans for reducing the standard of the production cost. Value engineering was first developed by GE, but its main purpose was to cut back on the cost of purchased components. The general characteristics of target cost management are as follows (Sakurai, 1989; Monden and Hamada, 1991; Choi, 1996).

First, unlike the standard costing that aims to achieve cost reduction at the production stage, target cost management is a cost-cutting activity that is applied from the product planning and design stages. This is because if the fundamental cost drivers that generate costs are not properly managed, this would result in a waste of labor as well as excessive production costs. Therefore, based on the experiential and logical truth that most costs are determined before production, it is important to draw up a cost-cutting plan before the cost drivers are fixed. Second, target cost management is not a means of controlling costs, but rather of planning and reducing costs. For this reason, target cost management is called cost planning. Third, target costing is more suitable for the assembly industry, which 
produces a small quantity of different products, than for the device industry, which is characterized by continuous production. This is due to the fact that it is difficult to achieve flexible product development and design in the device industry, where the production process is decided by the device input. However, due to business diversification, the production process of the device industry has developed into a form that also includes an assembly process. Firms that apply target cost management for these products have been increasing in number. Fourth, target cost management is used as a method to control design characteristics or product manufacturing technology. In this sense, this method is an engineering-oriented management technique rather than an accounting-oriented one. Thus, the successful operation of target cost management requires the application of other cost engineering techniques, such as value engineering and total quality control (TQC). Lastly, target cost management is related to the companywide strategic activities for pursuing profit acquisition under the limited conditions of the market environment. In the past, firms have adopted an internal-oriented approach, in which product design begins after the sales price is determined by adding the appropriate target profit after internal improvement is achieved. However, target cost management follows a market-oriented approach which calculates the target cost after the firm's target profit is deduced from the expected sales price in the target market, based on collected market information as shown in Fig. 2 below.

Figure 2. Market-oriented approach of target cost management

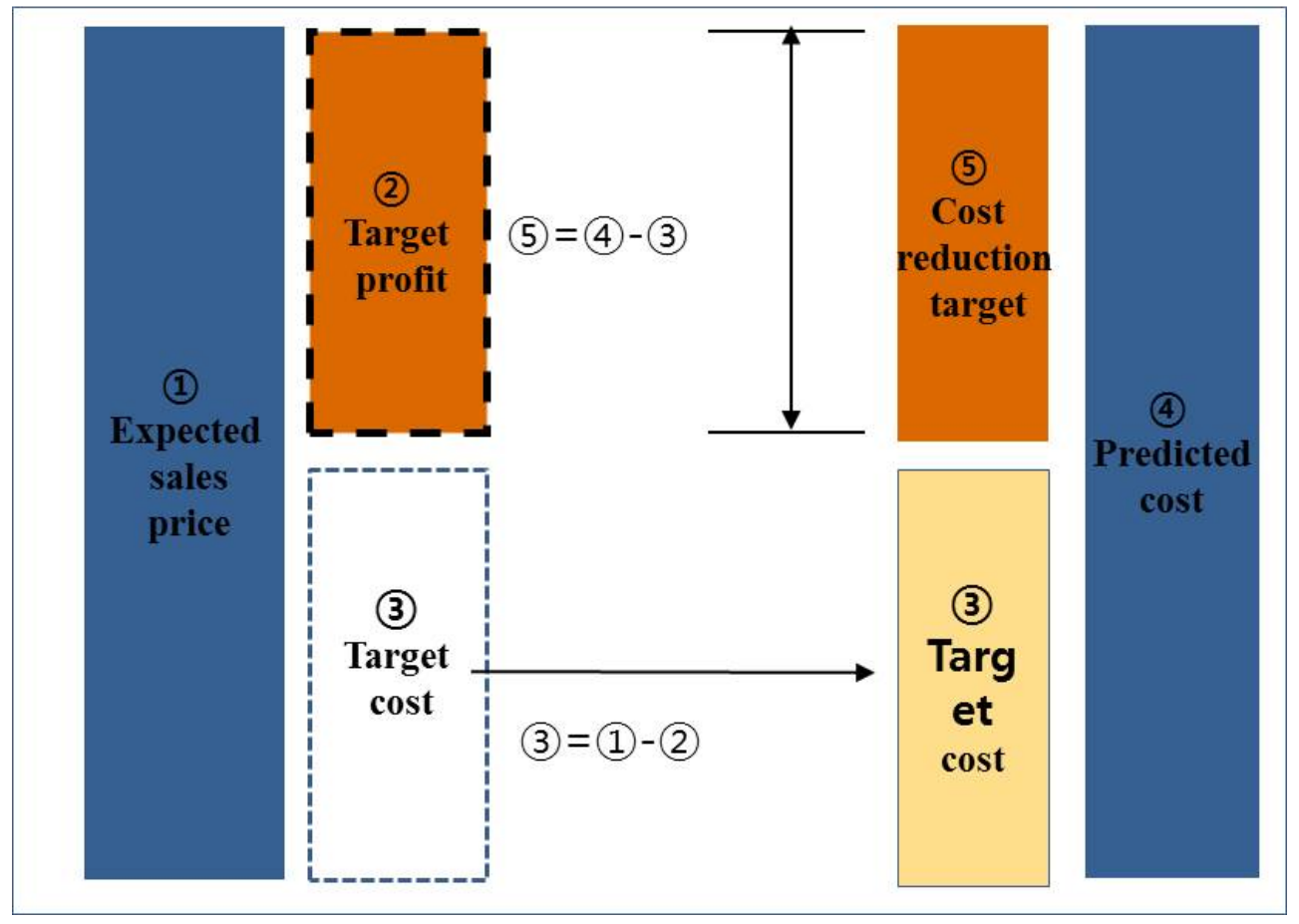

\section{CASE STUDY IN THE MANUFACTURING INDUSTRY}

\subsection{Summary description of A Company}

Company was founded as the A Technology Development Company and was separately established after acquiring the transmission. A Company focuses mainly on the production and sales of the following car components: transmissions, axles, and seats. As cars are expensive consumer durables, the automobile market is sensitive to economic ups and downs, showing a tendency to slow down significantly in times of recession. The commercial vehicle, which is the flagship product of A Company, is especially sensitive to fluctuations in the construction market, to the extent that construction orders serve as the indicator for commercial vehicle production. Furthermore, as vehicles are manufactured according to the orders received, planned production is not a viable option. For this reason, minimizing the inventory cost while securing a stable supply of components is a priority for the company that produces the complete vehicle, whereas for the component provider, collecting the information vital to 
production based on close cooperation with the complete vehicle producer is crucial. As of December 31, 2013, A Company employed 4,600 executives and staff members and had a turnover of 3.76 trillion won.

\subsection{Project Background}

A Company was in need of an innovative cost management system that would facilitate the construction of a proactive cost management system in response to the dominant market structure of complete cars. This system would facilitate the acquisition of internal cost competitiveness and strengthen the output of information essential to decision-making. In this light, A Company built a target cost management system in consideration of customer demands, rival relations, and the production environment. First, customers were pressuring the company to enlarge the scope of their cost-control and to continuously reduce prices under the dominant market structure of A \& B Motor. Second, A Company recognized a need for change in terms of becoming more cost-competitive in response to the intensified competition between firms and the expansion of cheap production sites, particularly in China. Third, various OEM business opportunities were expanded as a result of the enlarged company size which had been achieved through continuous business expansion and global market entry. Furthermore, the company faced limitations in cutting back on its processing costs due to the improved precision of the production process in the automated manufacturing environment.

For these reasons, in recognition of the need for change through an innovative cost management system, A Company finished building its target cost management system in July 2013. The system was designed to enable the company to consider the material costs that made up a large part of the production costs, to actively take measures in adjusting the levels of the production costs in comparison with the sales price demanded by customers, and to strictly meet the target production price in accordance with intensified global competition.

\subsection{Establishing the Automated Systems for Target Cost Management and Assessing Firm Performance}

The automated systems for target cost management and assessing firm performance aim for a significant reduction of the product costs by reviewing all cost-cutting opportunities at all stages, from the R\&D and design to production. In particular, target cost management systems consider the $\mathrm{R} \& \mathrm{D}$ and design stages to be important. In relation to this, A Company attempted to construct a target cost management system as shown in Fig. 3 below.

As presented in the figure below, the automated systems for target cost management and assessing firm performance process begins with the calculation of the estimated production cost. At this stage, the company uses the RFQ (request for quotation), BOM (bill of material), and expected sales price and other data to calculate the estimated cost of the new material. The company then receives the estimate sheet from the material cost supplier to review the validity of the material cost and decides whether or not to take the order. Afterward, the company sets the target for cost reduction and distributes it among the different parts. On the other hand, the production cost for each development phase is calculated and compared with the order price in order to analyze the differences in cost change, through which the degree of cost reduction and profitability can be analyzed. 
Figure 3. Automated system for target cost management and assessing firm performance of A Company

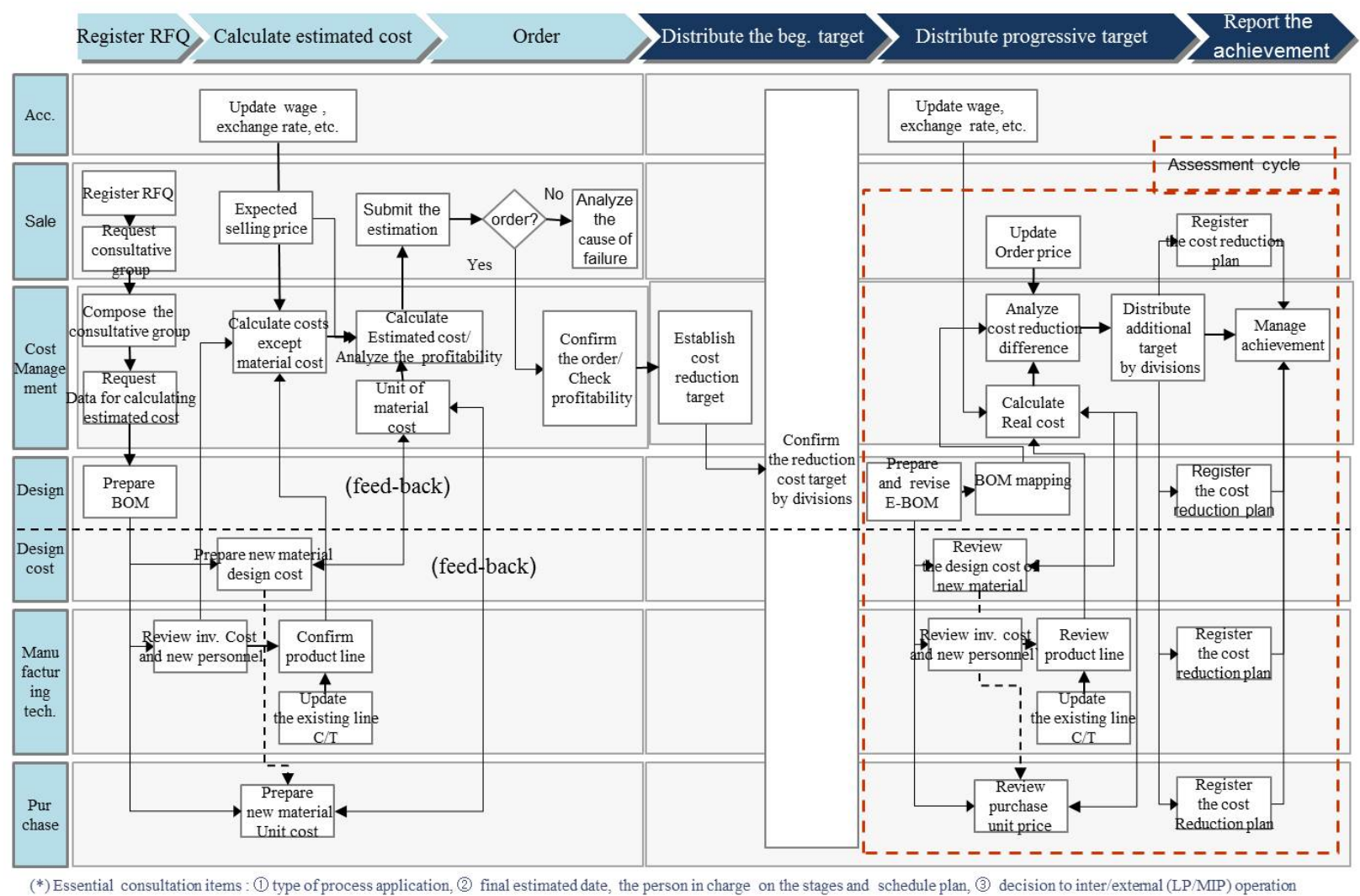

The automated system for target cost management and assessing firm performance constructed by A Company can be summarized as a system that (1) calculates estimated costs and analyzes profitability while (2) imposing and managing target costs. In particular, the profitability analysis process is carried out through an expected income sheet and sensitivity analysis by year or product. On the other hand, a Top-Down method is used for the target cost. Thus, the target cost is selected according to the target profit-to-sales price, it is segmented by item, and the results are considered by the managing department. Furthermore, the difference between the estimated cost and target cost is used to establish the cost reduction goal by cost item. The cost reduction plan for each managing department is confirmed and registered in the company systems to allow the relevant departments to manage their progress in accomplishing the goals.

\subsection{Important Issues in Building the Automated System for Target Cost Management and Assessing Firm Performance}

To successfully construct the automated system for target cost management and assessing firm performance, A Company improved the company cost management system in the 5 middle categories shown in Table 1. 
Table 1. Important issues for the target cost management system

\begin{tabular}{l|l|l}
\hline \multicolumn{1}{c|}{ Large category } & \multicolumn{1}{|c}{ Middle category } & \multicolumn{1}{c}{ Issues } \\
\hline $\begin{array}{l}\text { System for calculating } \\
\text { estimated cost and } \\
\text { analyzing profitability }\end{array}$ & $\begin{array}{l}\text { BOM management at estimation } \\
\text { stage }\end{array}$ & $\begin{array}{l}\text { Incomplete definition and standardization of BOM Level at } \\
\text { estimation stage } \\
\text { Incomplete analysis of material cost changes at development stage }\end{array}$ \\
\cline { 2 - 3 } & Calculation of material costs & $\begin{array}{l}\text { RFQ-based calculation of expected material costs } \\
\text { Material cost is calculated by purchasing division }\end{array}$ \\
& $\begin{array}{l}\text { Assessment of progress in } \\
\text { achieving reduction goal }\end{array}$ & $\begin{array}{l}\text { Absence of procedure for managing progress in achieving reduction } \\
\text { goal in development stage } \\
\text { Failure to analyze difference between profitability and actual cost }\end{array}$ \\
\hline $\begin{array}{l}\text { System for imposing } \\
\text { and managing target } \\
\text { cost }\end{array}$ & Standard of target profitability & $\begin{array}{l}\text { Confusion between target profitability and order validity } \\
\text { Failure to manage progress in achieving relevant project objectives } \\
\text { after order is obtained }\end{array}$ \\
\hline & $\begin{array}{l}\text { Distribution of reduction goal by } \\
\text { division }\end{array}$ & $\begin{array}{l}\text { Absence of target management standards by division after order is } \\
\text { obtained }\end{array}$ \\
\hline
\end{tabular}

As can be seen above, A Company had to improve the estimation stage BOM management, the material cost calculation, assessment of progress in achieving the reduction goal, target profitability standards, and distribution of the reduction goal at the estimation stage to successfully construct their target cost management system. First, in relation to the estimation stage BOM management, A Company lacked both the minimum standards for calculating the estimation stage material costs and a management system to track the changes in the prices of the materials used in the development of each component. Second, in relation to the material cost calculation, A Company did not compute the material costs through inter-departmental collaboration based on design information standards, but rather calculated the expected material costs based on the RFQ, with the purchasing division in charge of the estimation and management of new material costs. Third, A Company did not have a procedure for managing progress in achieving the reduction goals at the development stage. Owing to the lack of a process for receiving feedback after a business value review, the company was unable to achieve early analysis or response to issues related with expected profits and losses. Furthermore, the company did not have unified standards that could be applied to a whole project, but only analyzed the differences between profitability and actual costs if needed. Fourth, standards for target profitability were nonexistent in A Company. For example, the company only had reasonable profit rate standards at the order or estimation stages but not for the actual target profit of the project. Furthermore, A Company did not properly manage the progress made in achieving the relevant project objectives after the order was obtained. Lastly, A Company did not possess post-order target management standards for each department. In other words, the company lacked a procedure for consulting on departmental goals and there was no departmental consensus formed according to a Top-Down method. Thus, the progress in achieving the target goal was not reflected by the actual management system.

\subsection{Generating Solutions to the Automated System for Target Cost Management and Assessing Firm Performance Issues}

The following outlines the solutions adopted by A Company to solve the main issues mentioned in 3.4.

\subsubsection{System for Calculating the Estimated Costs and Analyzing Profitability}

The following tasks needed to be carried out to calculate the estimated costs and analyze profitability: registering the relevant project to calculate the estimated cost and implement a sensitivity analysis and profitability assessment based on the data. To construct this system, A Company established the following functions and programs for each task stage, as shown in Table 2. below. 
Table 2. Function and program by task stage

\begin{tabular}{|c|c|c|}
\hline Task stage & $\begin{array}{l}\text { Function } \\
\end{array}$ & $\begin{array}{c}\text { Program } \\
\end{array}$ \\
\hline 1. Project management & $\begin{array}{l}\text { - RFQ registration: manage OEM, product, } \\
\text { estimation type } \\
\cdot \text { Manage estimated cost calculation schedule and } \\
\text { managers }\end{array}$ & $\begin{array}{l}\cdot \text { Program registration } \\
\cdot \text { Management of schedule/managers }\end{array}$ \\
\hline $\begin{array}{l}\text { 2. Must-list registration and } \\
\text { new material cost } \\
\text { management }\end{array}$ & $\begin{array}{l}\cdot \text { BOM registration by product specification } \\
\cdot \text { Estimate new materials according to design cost, } \\
\text { unit price management } \\
\cdot \text { Manage estimated cost of purchase }\end{array}$ & $\begin{array}{l}\cdot \text { Registration of estimated BOM } \\
\cdot \text { Management of unit price of design } \\
\text { cost } \\
\cdot \text { Management of estimated cost of } \\
\text { purchase }\end{array}$ \\
\hline 3. New investment registration & $\begin{array}{l}\cdot \text { Register new investment factory, production line } \\
\text { and personnel information } \\
\cdot \text { Manage usage ratio by specification product }\end{array}$ & $\begin{array}{l}\cdot \text { Registration of new investment } \\
\cdot \text { Registration of estimated cost of } \\
\text { purchase }\end{array}$ \\
\hline $\begin{array}{l}\text { 4. Review of cost calculation } \\
\text { standards }\end{array}$ & $\begin{array}{l}\text { Review pay increase rate, inflation rate and } \\
\text { exchange rate } \\
\cdot \text { Designate production line }\end{array}$ & $\begin{array}{l}\cdot \text { Management of standard information } \\
\cdot \text { Designation of production line }\end{array}$ \\
\hline 5. Calculation of estimated cost & $\begin{array}{l}\text { - Calculate estimated cost by product specification } \\
\text {-Write yearly income statement }\end{array}$ & - Calculate estimated cost \\
\hline $\begin{array}{l}\text { 6. Sensitivity/ profitability } \\
\text { analysis }\end{array}$ & $\begin{array}{l}\text { - Analyze effect of change in exchange rate of } \\
\text { estimated price, pay increase rate } \\
\text { - Analyze project profitability }\end{array}$ & $\begin{array}{l}\cdot \text { Record and calculate sensitivity } \\
\text { variables } \\
\cdot \text { Profitability analysis }\end{array}$ \\
\hline
\end{tabular}

Figure 4 presents the system for calculating the estimated costs and analyzing profitability that was constructed by A Company on the basis of the functions and programs detailed above.

Figure 4. System for calculating the estimated costs and analyzing profitability

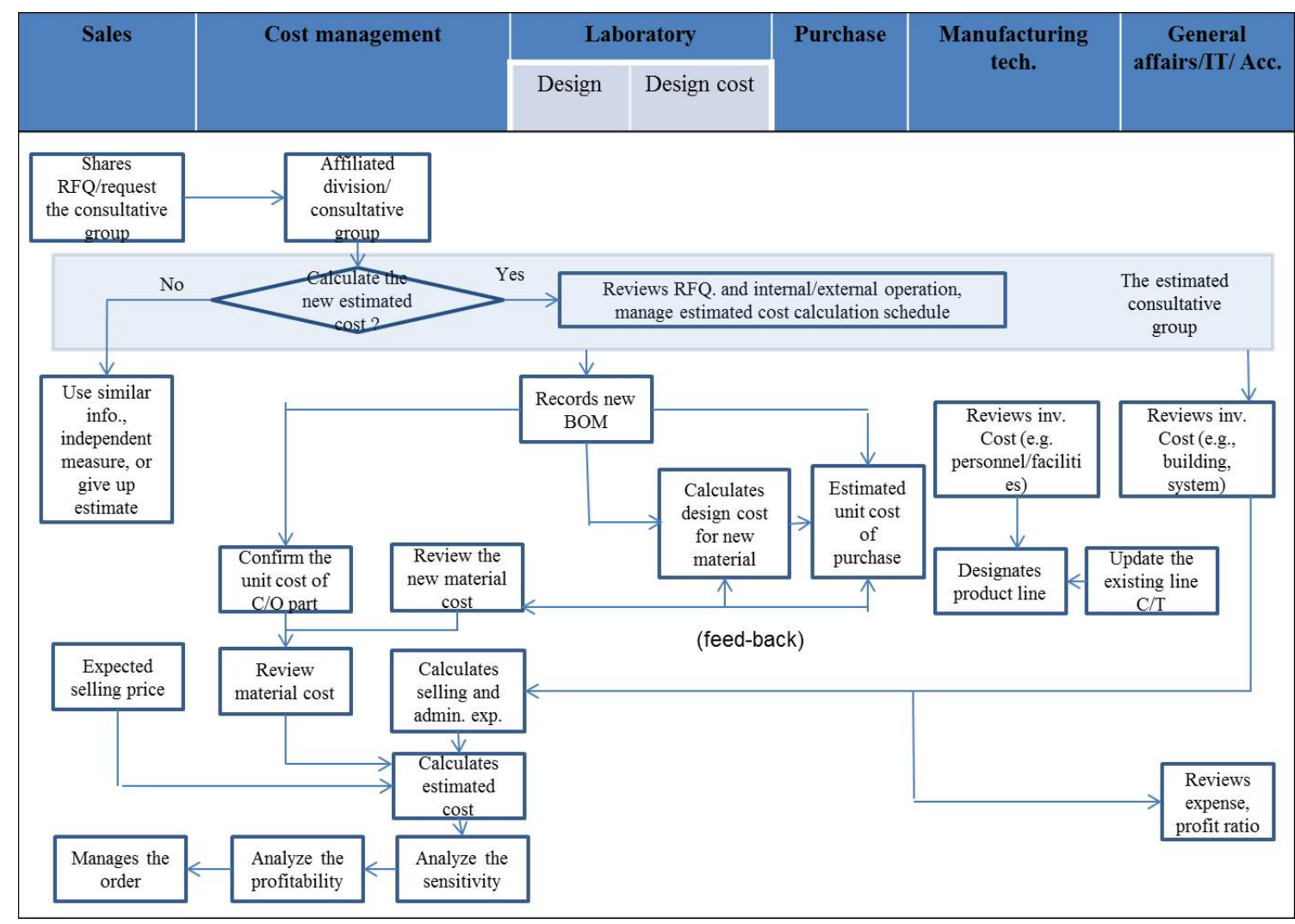


The important parts of the system for calculating the estimated costs and analyzing profitability are as follows.

\subsubsection{Composition of RFQ Registration and Order Consultative Group}

After the sales division receives the RFQ from the customer, the sales department registers the RFQ in the cost system. When the order project code for the relevant RFQ is created, the main information of the RFQ is entered into the system. The sales division registers the person in charge of calculating the estimated cost in the cost system and sends an e-mail requesting the calculation of the estimated cost. The cost management division checks the RFQ information through the e-mail sent by the sales division and plans the entire estimate schedule after checking the schedule of the estimate consultative group. The consultative group - composed of the sales division, cost management division, design division, purchasing division, manufacturing division and technology division - then holds consultations on the calculation of the estimated cost, the internal/external work classification and the schedule. This information is summarized in Figure. 5.

Figure 5. Composition of RFQ registration and order consultative group

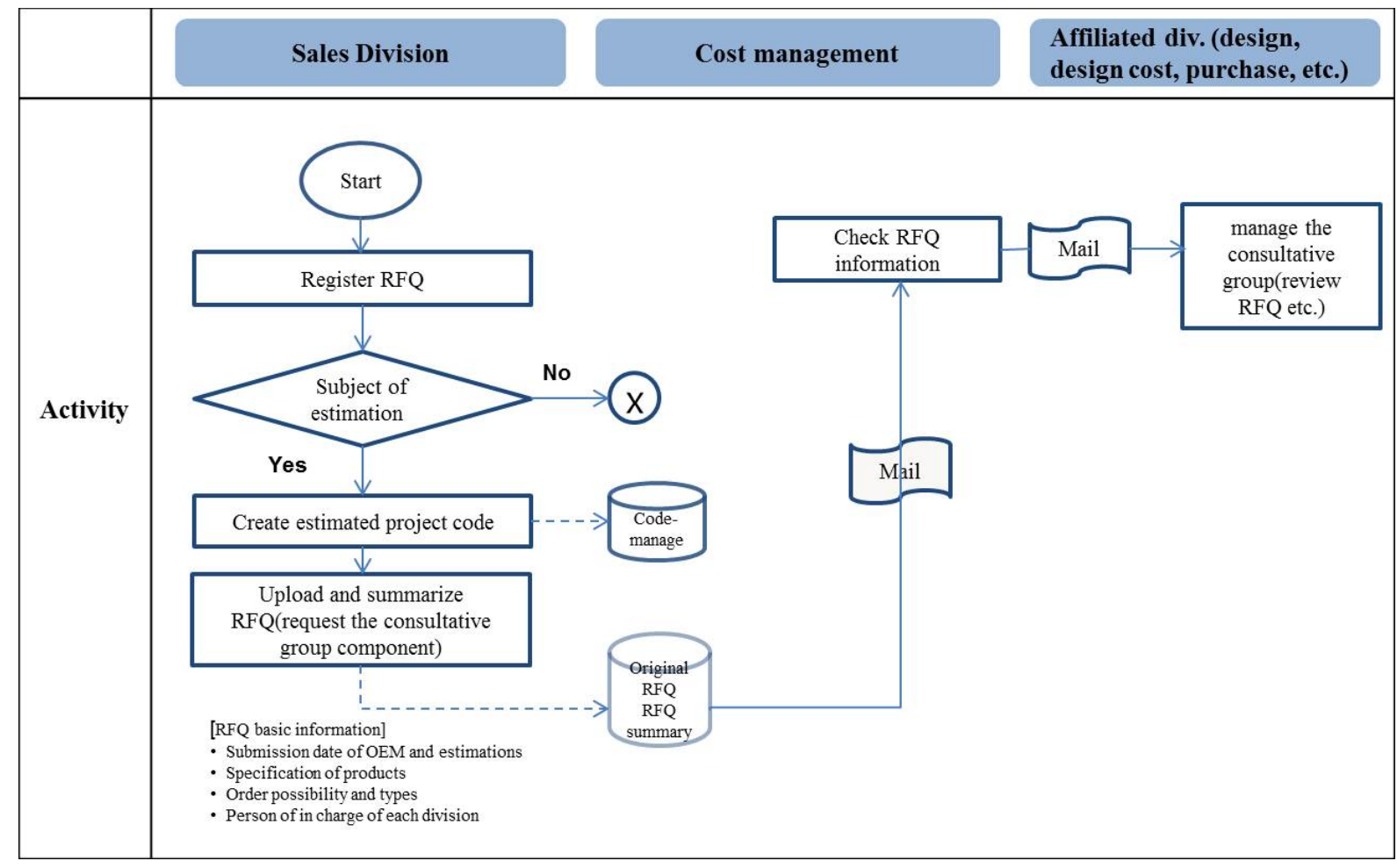

\subsubsection{Selection of Product for Estimated Cost Calculation}

Estimate consultative groups are formed according to the RFQ to decide whether to include the subject of estimation. The sales division then determines whether the subject is calculated in the cost management division according to the judgment criteria established by the cost management and sales divisions, or is provided with similar specifications in the cost management system as an independent measure taken by the sales division. If the subject requires a regular process response, the external/internal task implementation is primarily examined by considering the work schedules of the different departments. The cost management division registers the cost-related schedules decided by the estimate consultative group and data requests are sent by e-mail to the affiliated divisions, such as manufacturing, technology and sales.

On the other hand, in case the process is carried out independently by the sales division, a sensitivity analysis is conducted to calculate the estimated comparative cost if specifications similar to those of the estimated product 
already exist among the order records in the cost system. If the sales division does not take independent measures, the division will record the reasons for giving up on the submission of the estimated price and save the information in the order record management table. The above process is summarized in visual form in Figure 6.

Figure 6. Selection of production for estimated cost calculation

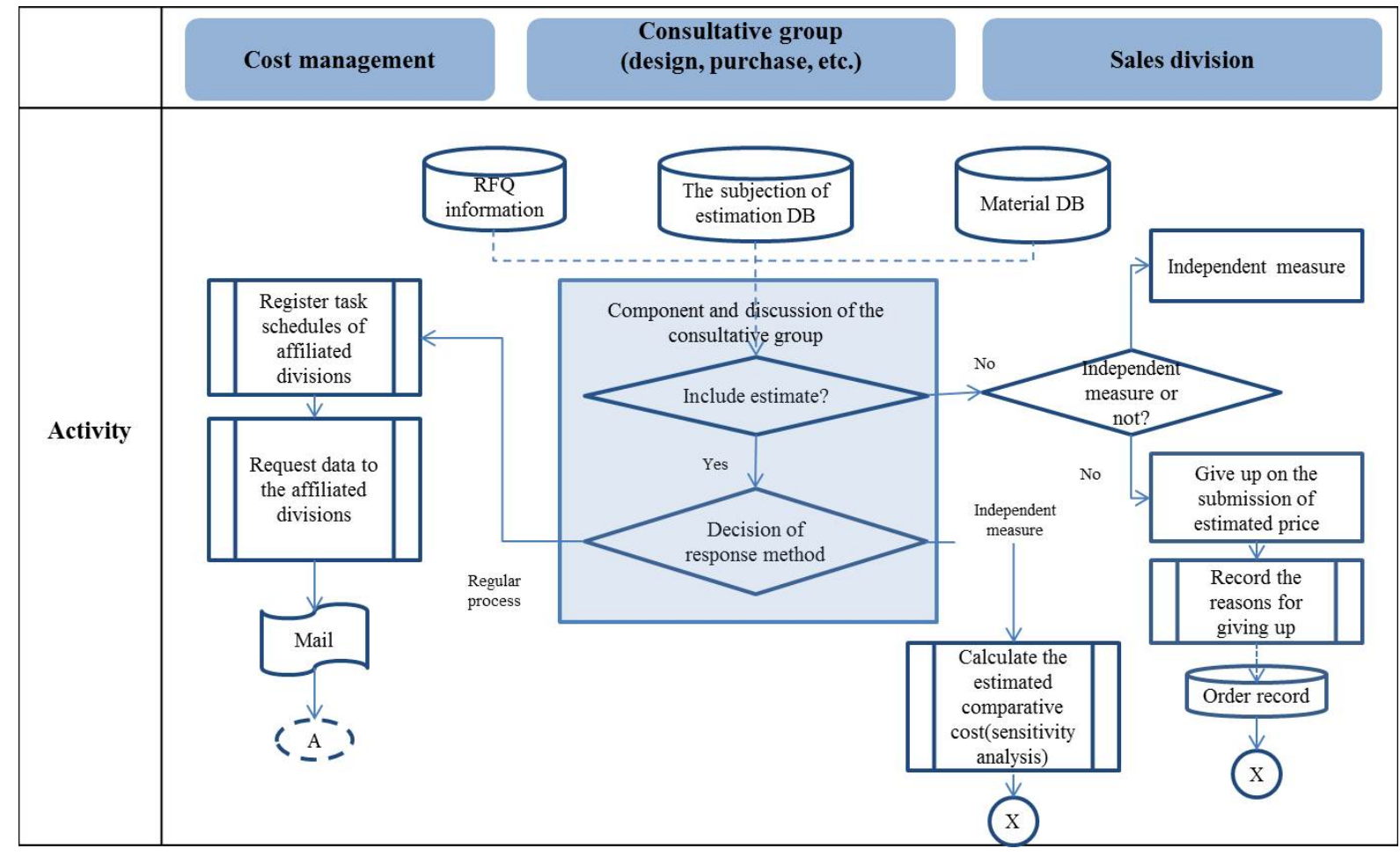

\subsubsection{Preparing of Estimated BOM and Calculation of Component Price}

The design division is responsible for preparing the general BOM in consideration of the RFQ requirements and for registering the estimated BOM in the cost management system so as to share the information with the other divisions in charge of the cost calculation. The cost management divisions, design cost division and purchasing division receive the estimated $\mathrm{BOM}$ information written by the design division and collect the price information in order to analyze the relevant material. Meanwhile, the design cost division checks the C/Over material through PIMS and calculates the unit price of the new material in consideration of the new specifications.

The purchasing department checks the C/Over material through PIMS and checks the information on the unit price of the new material written by the design cost division. By using methods such as comparative analyses, the purchasing unit cost of the new material is estimated. Afterward, the cost management division reviews and confirms the estimated BOM design cost and the estimated unit price of the new material given by the purchasing department to add the unit price information to the estimated BOM composition/quantity data. The above process is summarized in Figure 7. 
Figure 7. Preparing of estimate BOM and calculation of component price

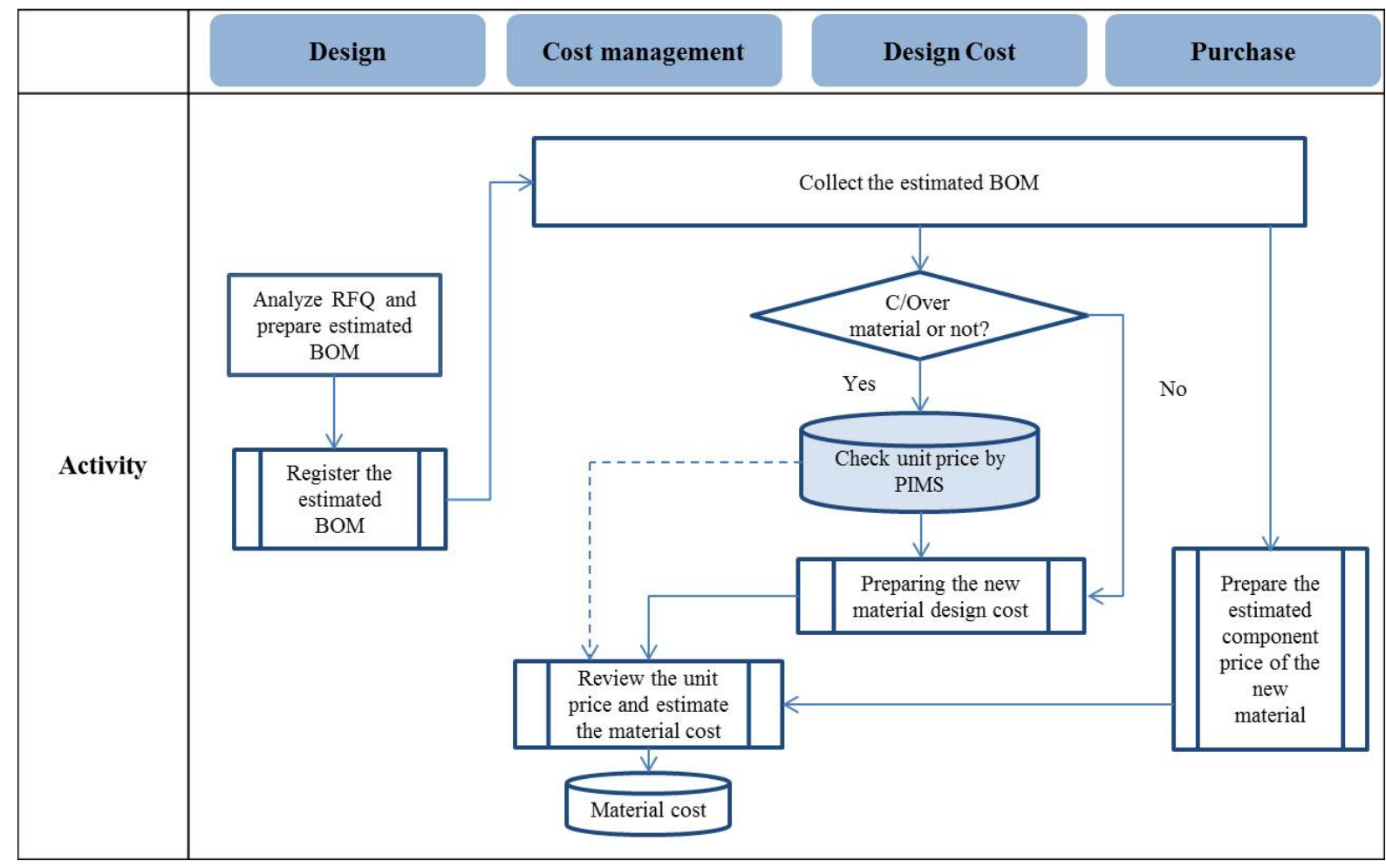

\subsubsection{Review and Calculation of New Personnel and Investment Costs}

In reference to the RFQ information and the data provided by the design division (BOM list), the manufacturing technology division analyzes the required personnel input and investment cost and examines whether the existing assembly lines can be used, or new factories or assembly lines need to be constructed. In cases of new investment, the manufacturing technology division calculates the additional input in terms of project personnel, wage and investment cost for each process and registers the related information (e.g. the investment price for new lines, the year/month of depreciation, the number of new personnel, the wage and usage ratio by product specification) in the cost management system of the company. The general affairs and IT divisions register the related investment information (e.g. new asset investment cost, year/month of depreciation, durable period, usage ratio by product specification) in which the newly invested amount, computer equipment, software and other new investment costs have been reviewed. The manufacturing technology division designates the new lines to be applied by product specification. The above process is summarized in Figure 8. 
Figure 8. Review and calculation of new personnel and investment costs

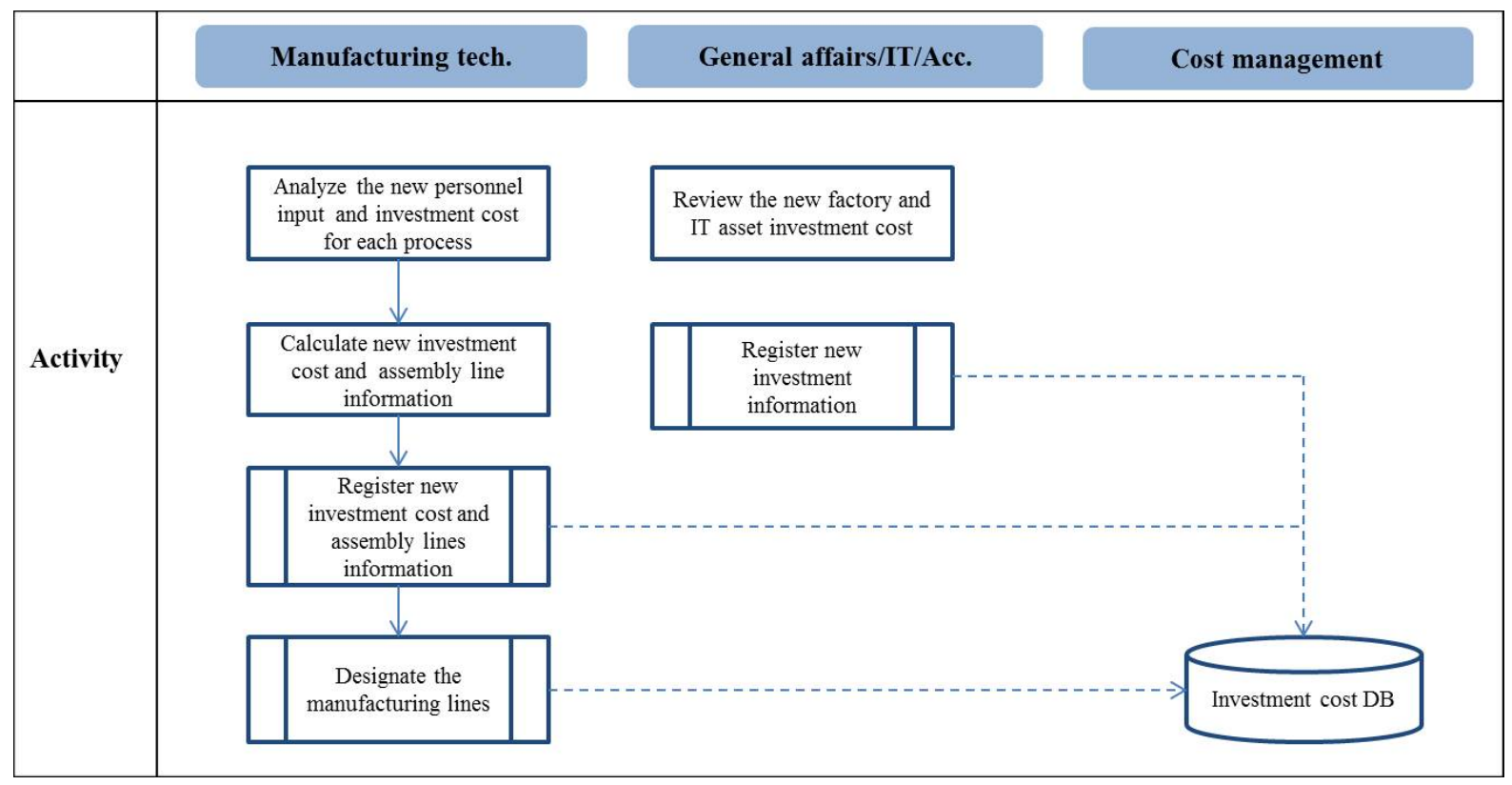

\subsubsection{Calculation of Estimate Standard Price}

The cost management division reviews and confirms the RFQ information registered by the sales division (product, production record, quantity, SOP, project period, etc.). Meanwhile, the annually updated information on cost standards (e.g. pay increase rate, inflation rate, business record ratio, etc.), RFQ quantity, expected sales price and investment price by production line are also checked. Furthermore, the division calculates the material cost, labor cost in consideration of quantity and unit price specified in the material cost database and estimates the depreciation cost and manufacturing expenses for the equipment, factories and building of new assembly lines. The selling and administrative expenses are calculated based on the expected sales price recorded by the sales division, and the financial profits/costs and other profits/costs are calculated with reference to the business performance and inflation rate.

Meanwhile, the recorded sales price, production cost and selling and administrative expenses, including the material cost, are aggregated to calculate the estimated cost. Afterward, a sensitivity analysis (e.g. quantity, exchange rate, investment cost, pay increase rate, inflation rate, etc.) is conducted based on the calculated order cost and the related results in terms of profitability are examined. Furthermore, based on the data examined in the sensitivity analysis, the estimated cost is confirmed, and the estimated cost included in the profitability analysis data is shared with the sales department. The above process is summarized in Figure 9. 
Figure 9. Calculation of estimate standard price

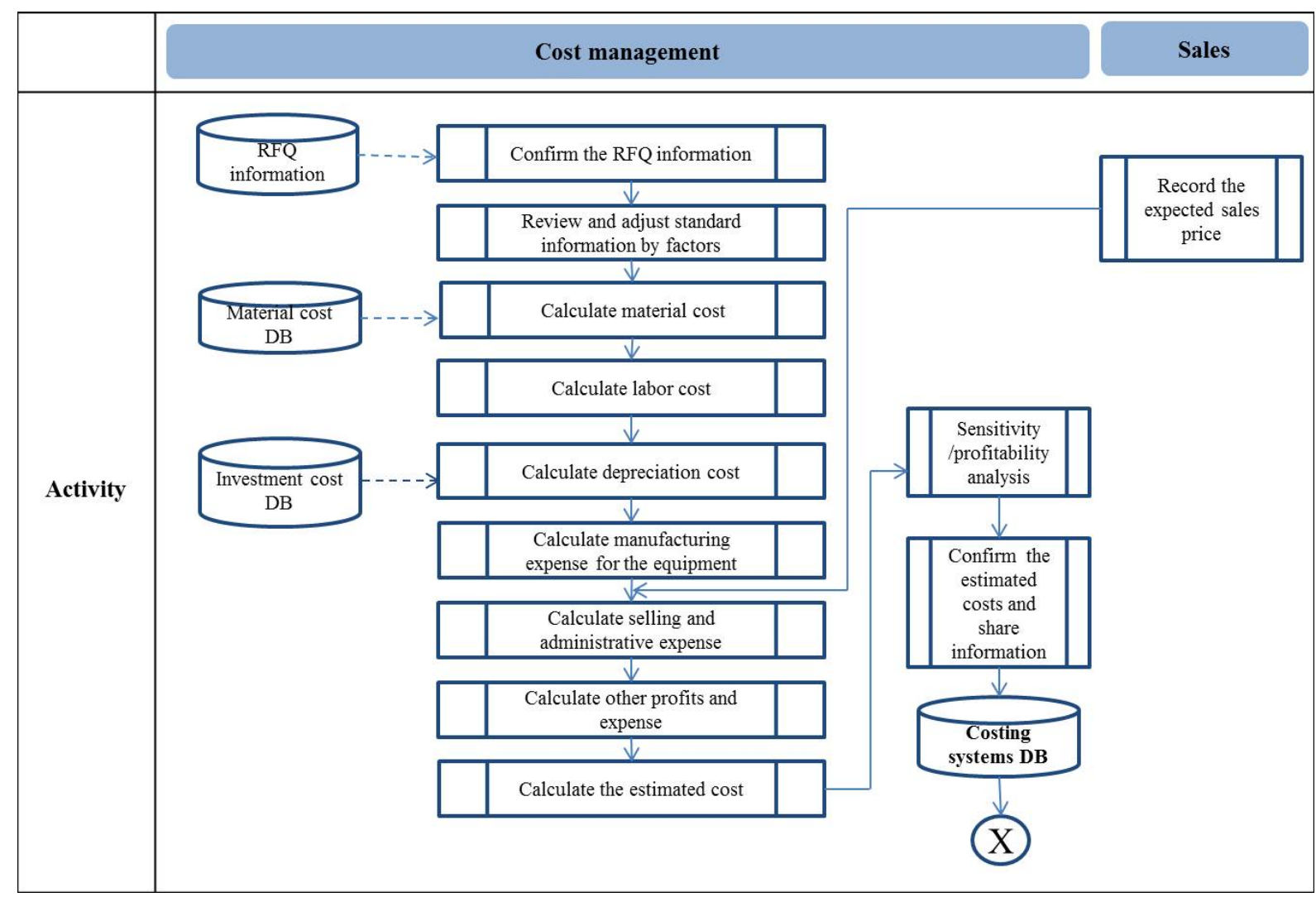

\subsubsection{Profitability Analysis}

The cost management department calculates the order sales price, order sales quantity, estimated cost and depreciation cost through EBITDA. Furthermore, (1) the increase in net working capital is calculated through the receivables turnover, inventory turnover, and payable turnover ratios, (2) the CAPEX investment is calculated through the amount of new investment by project (3) and the corporate tax for EBIT is calculated from the EBIT and corporate tax rate. The financing plans established for the investment are used to obtain information on the debt, capital and cost of outside capital, which are in turn used to calculate the discount rate. Lastly, through the estimation data above, the NPV or payback period is calculated based on the cash inflow/outflow and discount rate. The above process is summarized in Figure 10. 
Figure 10. Profitability analysis

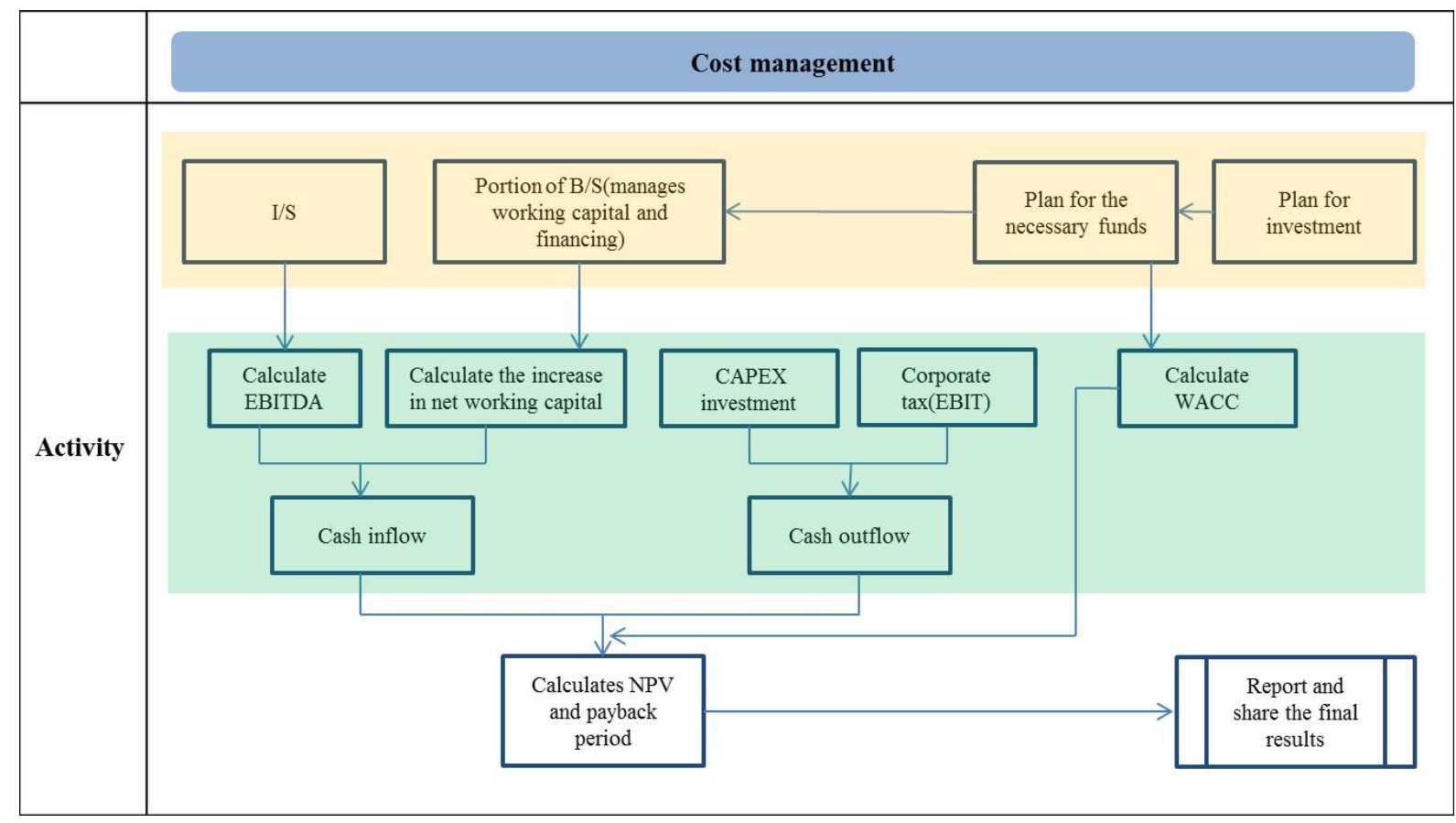

\subsubsection{Post-Order Management}

Once the order is confirmed, the sales division confirms the RFQ order submitted during the estimation. Furthermore, the results of the independent estimation by the sales division also become subject to order record management once the order has been confirmed. After confirmation, the RFQ-related information is updated. On the other hand, the reasons for order failure are registered if the order is not successfully placed. The above process is summarized in Figure 11.

Figure 11. Post-Order Management

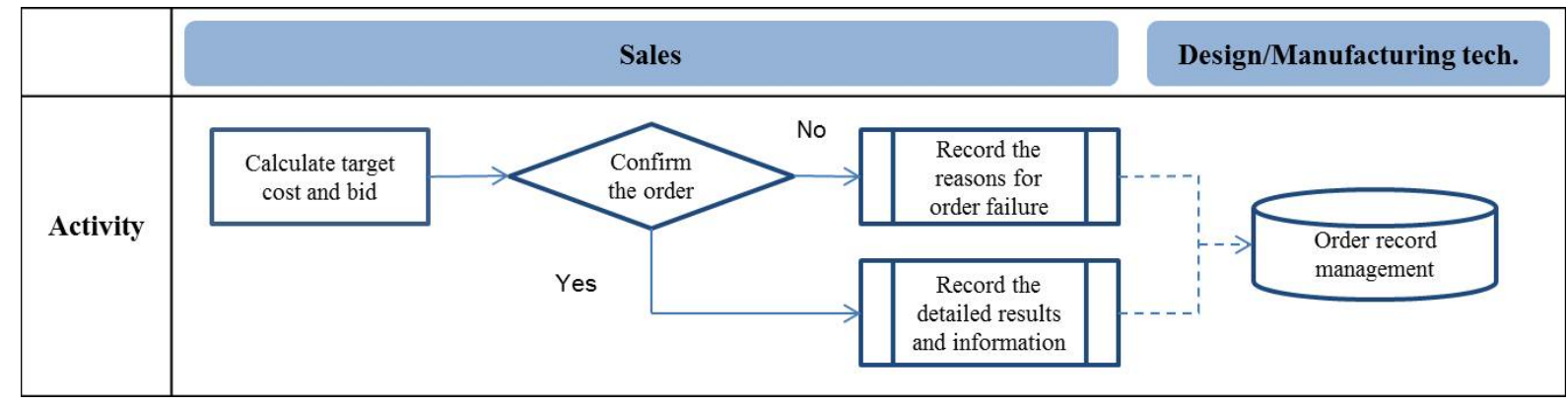

\subsubsection{System for Imposing and Managing Target Cost}

The system for imposing and managing the target cost must include a function to select the project for management, to specify the target profit rate and the reduction goals for the different divisions and to provide feedback on the results of the cost reduction activities. To construct this system, A Company established the functions and programs by task stage shown in Table 3. below. 
Table 3. Functions and programs by task stage

\begin{tabular}{|c|c|c|}
\hline Task stage & Function & Program \\
\hline $\begin{array}{l}\text { 1. Selection of subject } \\
\text { for target cost } \\
\text { management }\end{array}$ & $\begin{array}{l}\cdot \text { Designate project and main specifications } \\
\cdot \text { Manage main basic information (e.g. sales information, } \\
\text { development period, manager, etc.) }\end{array}$ & $\begin{array}{l}\cdot \text { Creation of target cost codes } \\
\cdot \text { Registration and management of basic } \\
\text { information }\end{array}$ \\
\hline $\begin{array}{l}\text { 2. Selection of target } \\
\text { cost }\end{array}$ & $\begin{array}{l}\cdot \text { Establish target profit rate } \\
\cdot \text { Decide total target cost and division goals }\end{array}$ & $\begin{array}{l}\cdot \text { Registration of target profit rate } \\
\cdot \text { Registration of cost reduction goals by } \\
\text { division }\end{array}$ \\
\hline $\begin{array}{l}\text { 3. Establishment and } \\
\text { implementation of } \\
\text { reduction plans }\end{array}$ & - Establish detailed cost reduction plans by division & $\cdot$ Registration of cost reduction plan \\
\hline $\begin{array}{l}\text { 4. Calculation of real } \\
\text { cost }\end{array}$ & $\begin{array}{l}\text { - Calculate current material cost and processing cost } \\
\text { - Analyze difference between target and real cost }\end{array}$ & $\begin{array}{l}\cdot \text { Calculation of real cost } \\
\cdot \text { Difference analysis }\end{array}$ \\
\hline $\begin{array}{l}\text { 5. Assessment and } \\
\text { feedback for mid- } \\
\text { level achievement }\end{array}$ & $\begin{array}{l}\cdot \text { Analyze specific causes of difference } \\
\cdot \text { Assess degree of target achievement } \\
\cdot \text { Re-distribution by division }\end{array}$ & $\begin{array}{l}\cdot \text { Registration of specific causes for } \\
\text { difference } \\
\cdot \text { Re-distribution of goals according to } \\
\text { stages }\end{array}$ \\
\hline $\begin{array}{l}\text { 6. Assessment of } \\
\text { performance } \\
\text { achievement }\end{array}$ & $\begin{array}{l}\text { Calculate actual production cost } \\
\text { - Assess target achievement of mass production cost } 6 \\
\text { months after SOP }\end{array}$ & $\begin{array}{l}\cdot \text { Actual BOM cost } \\
\cdot \text { Final achievement assessment }\end{array}$ \\
\hline
\end{tabular}

Figure 12 presents the system for imposing and managing the target cost that was constructed by A Company based on the functions and programs explained above.

Figure 12. System for imposing and managing target cost

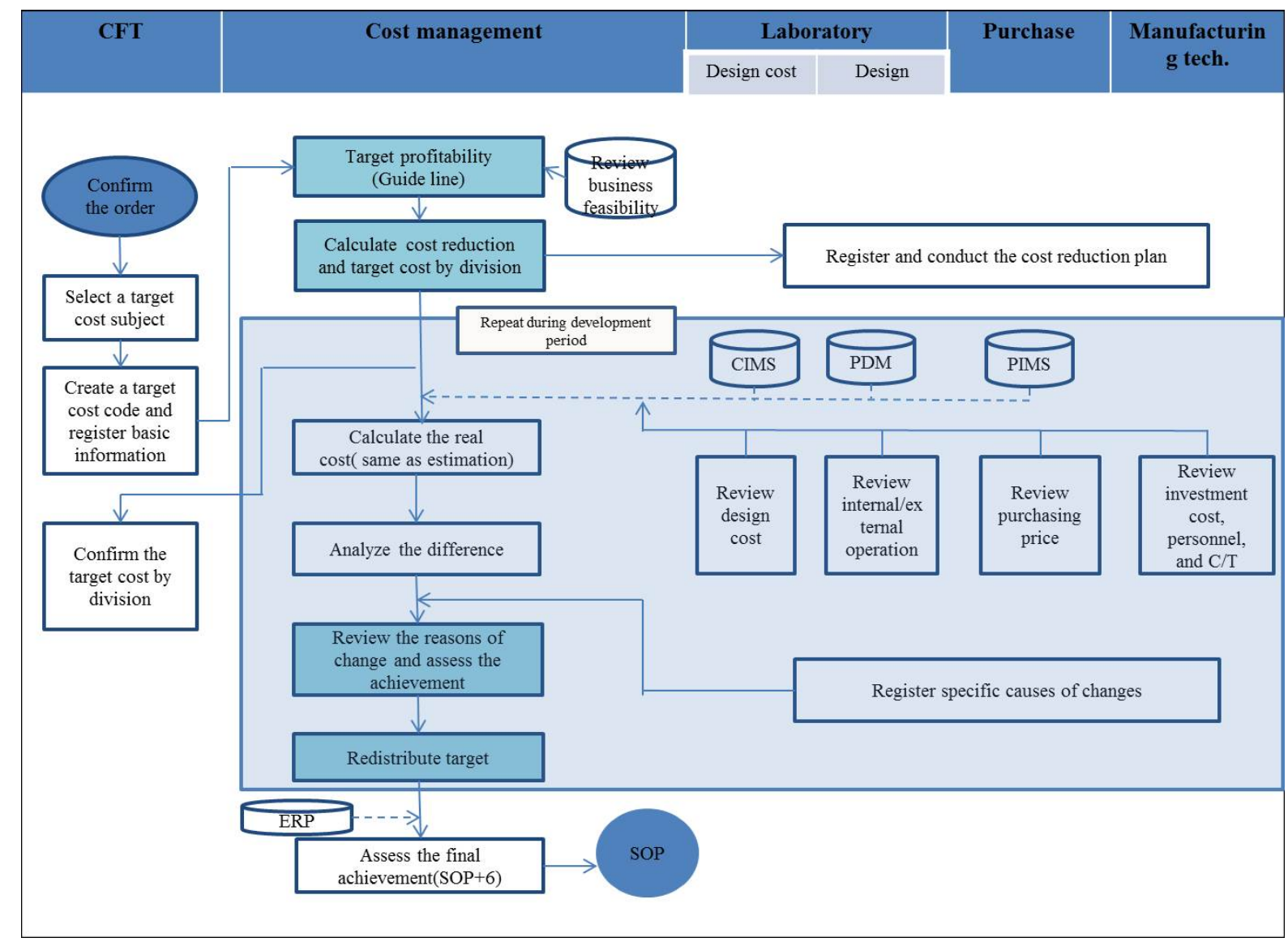


The important parts of the system for imposing and managing the target cost are as follows.

\subsubsection{Selection of Target Cost Subject}

When the sales division confirms the order, the cost management division selects the type and specifications of the subject for the target cost management and creates a target cost management code. Furthermore, using the transferred results of the estimated cost calculation and the profitability analysis, the division decides whether to recalculate the real cost for target-setting. In this case, the accepted principle is to use the final estimated cost without re-calculating the real cost. However, if changes were made to the specifications after the final estimation, the real cost must be calculated again. On the other hand, if the real cost is re-calculated, the division must conduct a review to decide whether to conduct internal or external operations. Afterward, the schedules for the mid-level assessment and target achievement are established after registration of the managers in the affiliated departments and of basic project information. The above process is summarized in Figure 13.

Figure 13. Selection of target cost subject

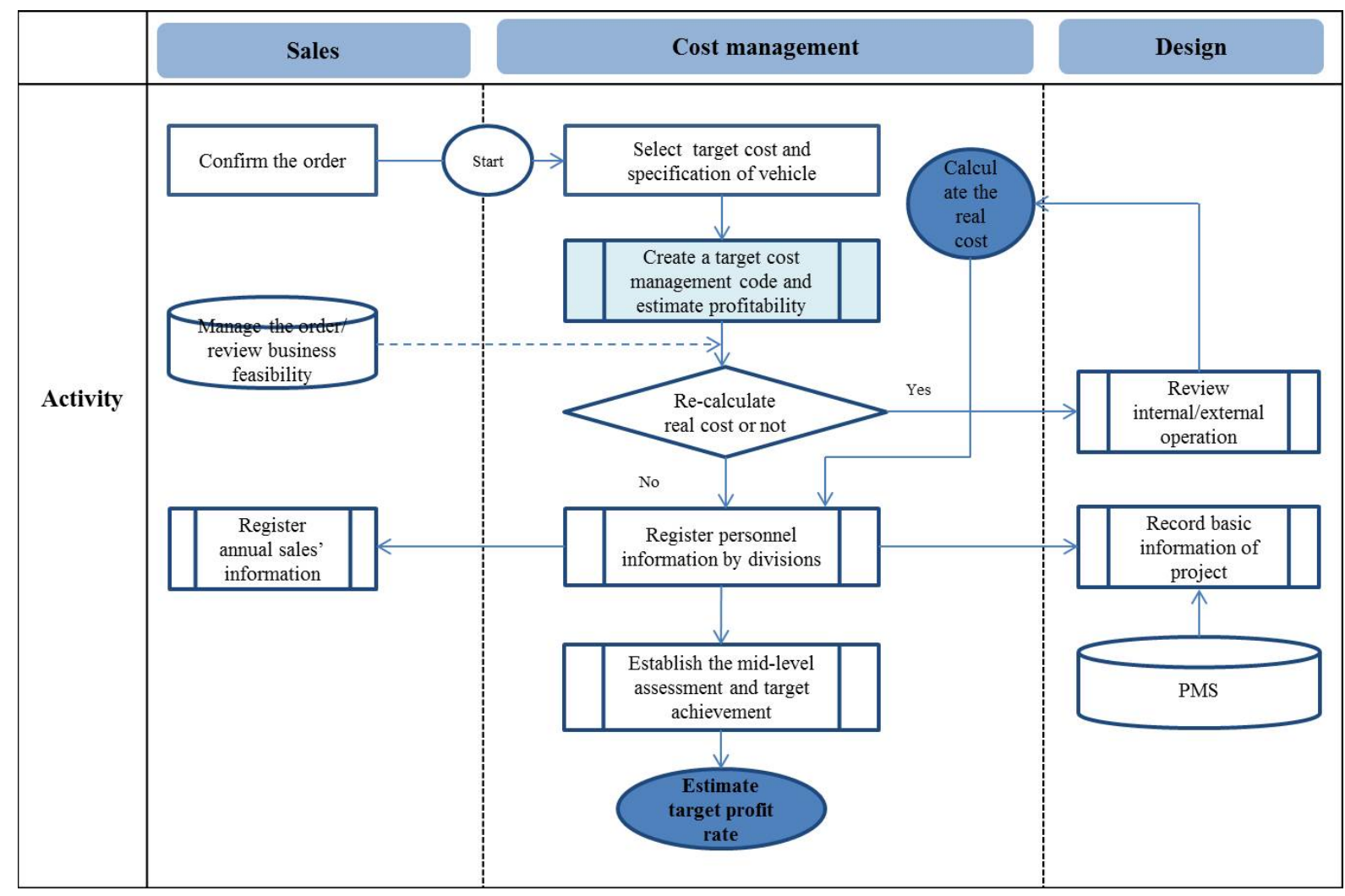

\subsubsection{Selection of Target Profit Ratio}

The cost management division uses the business feasibility review data and the ordinary profit ratio of the whole business to produce the guidelines for the target profit ratio. Afterward, all divisions, including the sales, design, purchasing and manufacturing technology divisions, discuss whether to accept the guidelines for the target profit ratio as well as the mediation plan with reference to the final target profit ratio of the project and the target reduction potential of each division. In this case, if there is a reason for adjusting the target profit ratio, the cause must be reviewed before registering the confirmed target profit ratio. The amount that must be reduced in each division is calculated through this process. The above process is summarized in Figure 14. 
Figure 14. Selection of target profit ratio

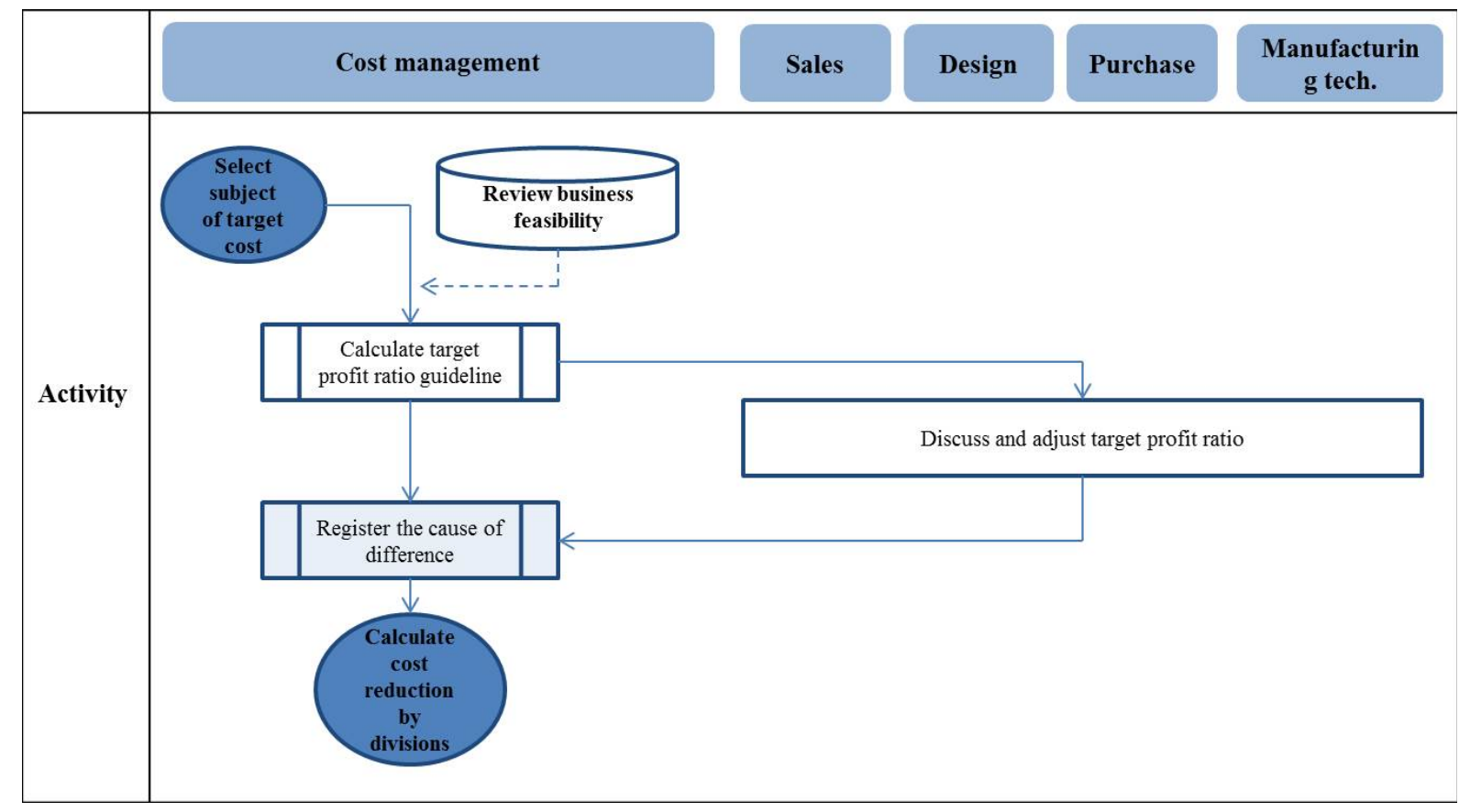

\subsubsection{Distribution of Target Reduction Plans Among Divisions}

The cost management division uses the latest sales price and target profit ratio in order to calculate the total target cost. The real cost (the estimated cost during the initial target establishment) is used to produce the 'guidelines for division distribution', which allocate the cost by divisions based on the ratios of the cost items. On the other hand, the target sales price is assigned to the sales division. After these targets are set, notification e-mails are sent to the design, purchasing and manufacturing technology divisions. Each division reviews the need for target adjustment by considering the management status and the likelihood of achieving the goal. Afterward, all divisions register their activity plans for achieving their reduction goals. The cost management division checks and confirms the contents of the registered reduction plans and each division carries out the relevant reduction activities. The above process is summarized in Figure 15. 
Figure 15. Distribution of target reduction plans among divisions

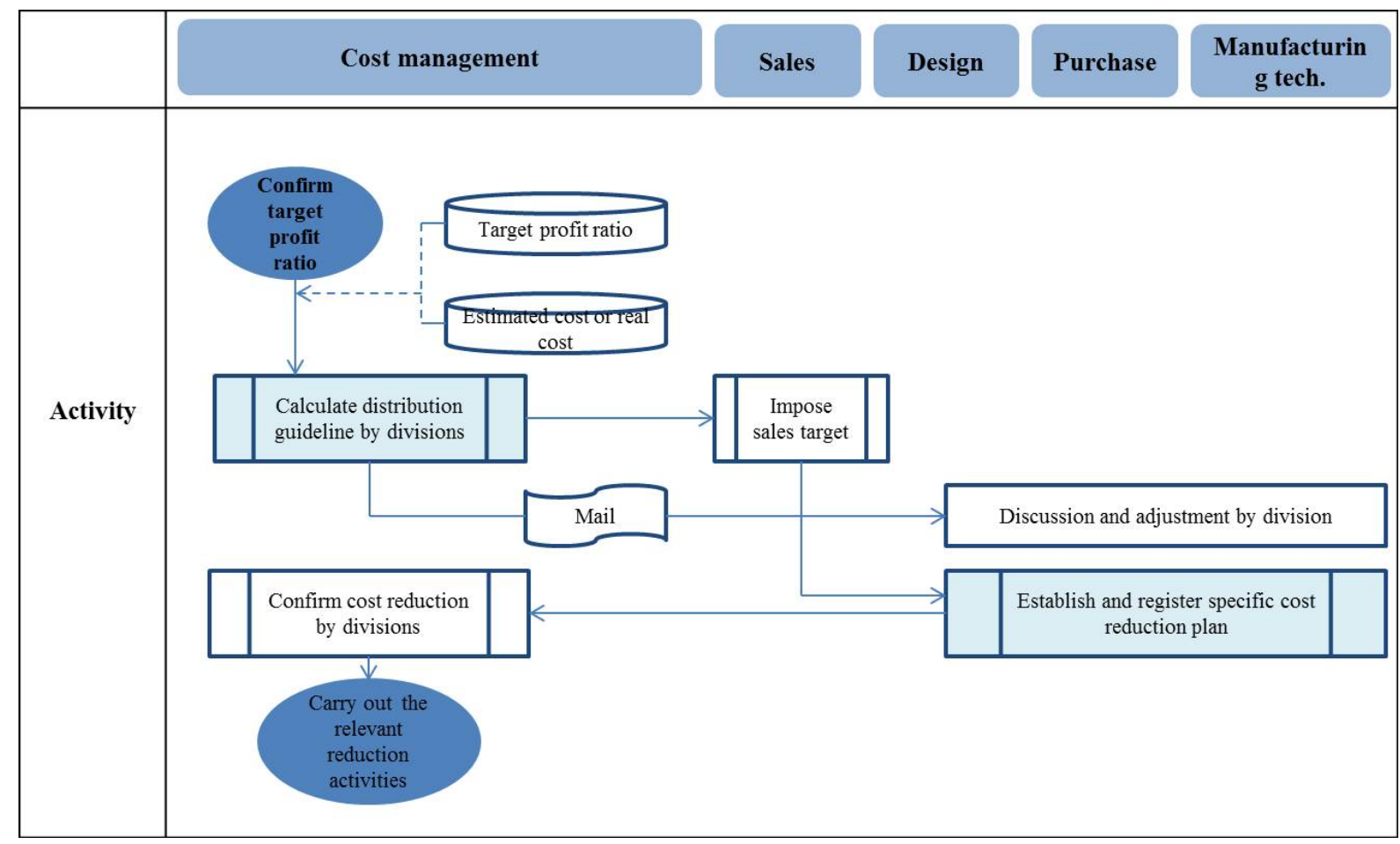

\subsubsection{Calculation of Real Cost by Stage}

The cost management division begins with a calculation of the real cost in order to assess the mid-level achievement. To achieve this, the division requests the design cost and for the purchasing, design and manufacturing technology divisions to record and register the basic data required for the calculation of the real cost. The design division registers the BOM containing the latest data and updates the BOM based on the revised floor plan. The manufacturing technology division records the basic data for estimating the processing costs and re-examines the internal/external operations, investment cost and personnel by observing the revised floor plan. The design cost division re-calculates the design cost based on the modified BOM, whereas the purchasing division re-examines the expected sales price.

At the same time, the cost management division confirms the predicted cost of the new material in reference to the development cost recorded by the design and purchasing divisions. Afterward, the sales division registers the updated sales price that has been modified due to changes in specifications and price negotiations, whereas the cost management division calculates the material cost, processing cost, sales price, and selling and administrative expenses to confirm the real cost. The above process is summarized in Figure 16. 
Figure 16. Calculation of real cost by stage

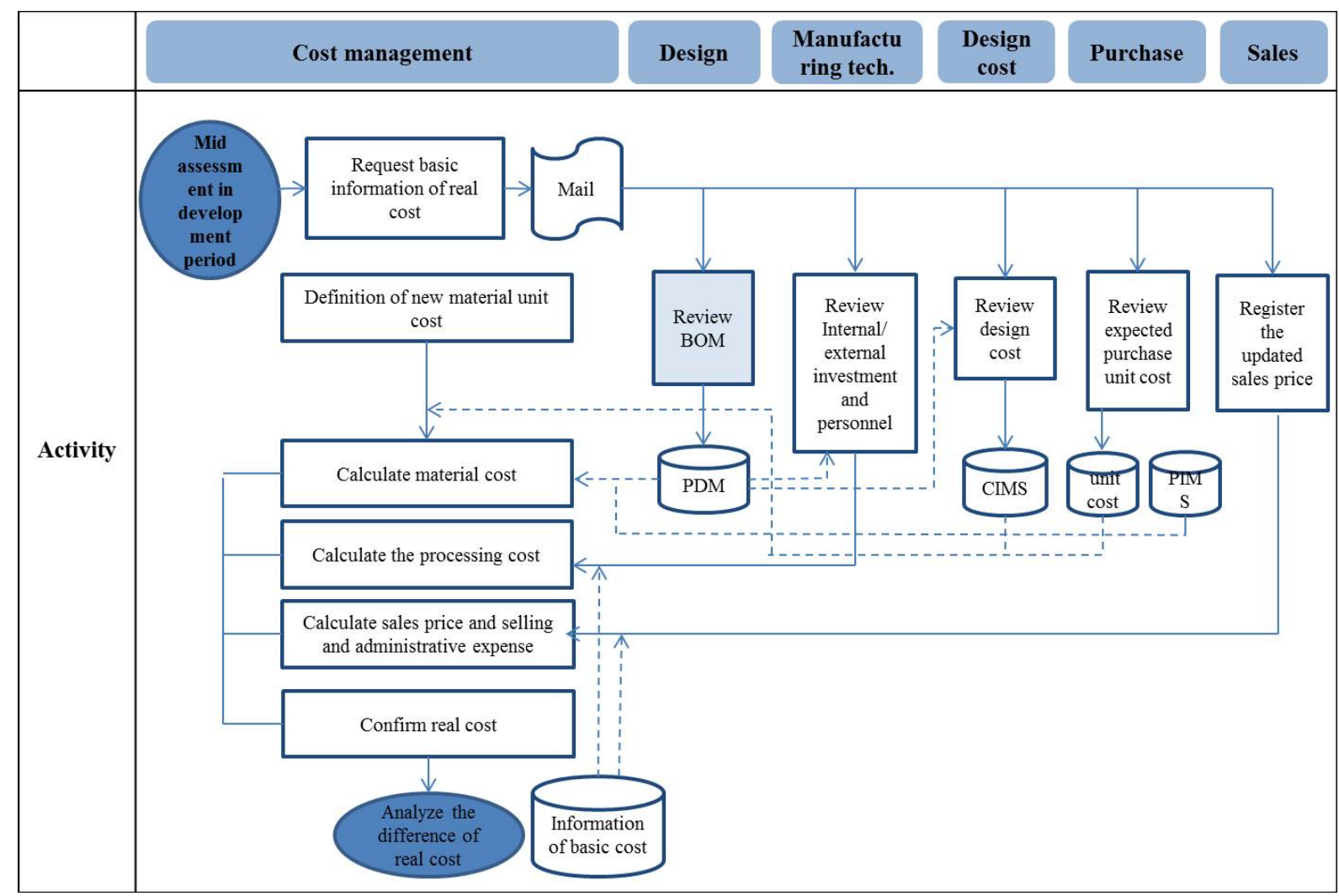

\subsubsection{Difference Analysis of Real Cost}

The cost management division compares the real cost as calculated by cost item and the real cost (or estimated cost) of the previous stage to analyze the differences. The design division compares the present BOM with the BOM of the previous stage to map the material records that have been modified, added, or deleted. The cost management division then requests the purchasing, design, manufacturing technology, and sales divisions to register the detailed causes and activities which explain the real cost differences. Afterward, each division registers the specific activities that triggered these differences and provides feedback on the results of the achievement assessment.

The cost management division checks whether the registered content is reasonable and requests the re-registration of inappropriate content. The division also confirms the detailed reasons for the cost difference so as to complete the cost difference analysis. The above process is summarized in Figure 17. 
Figure 17. Difference analysis of real cost

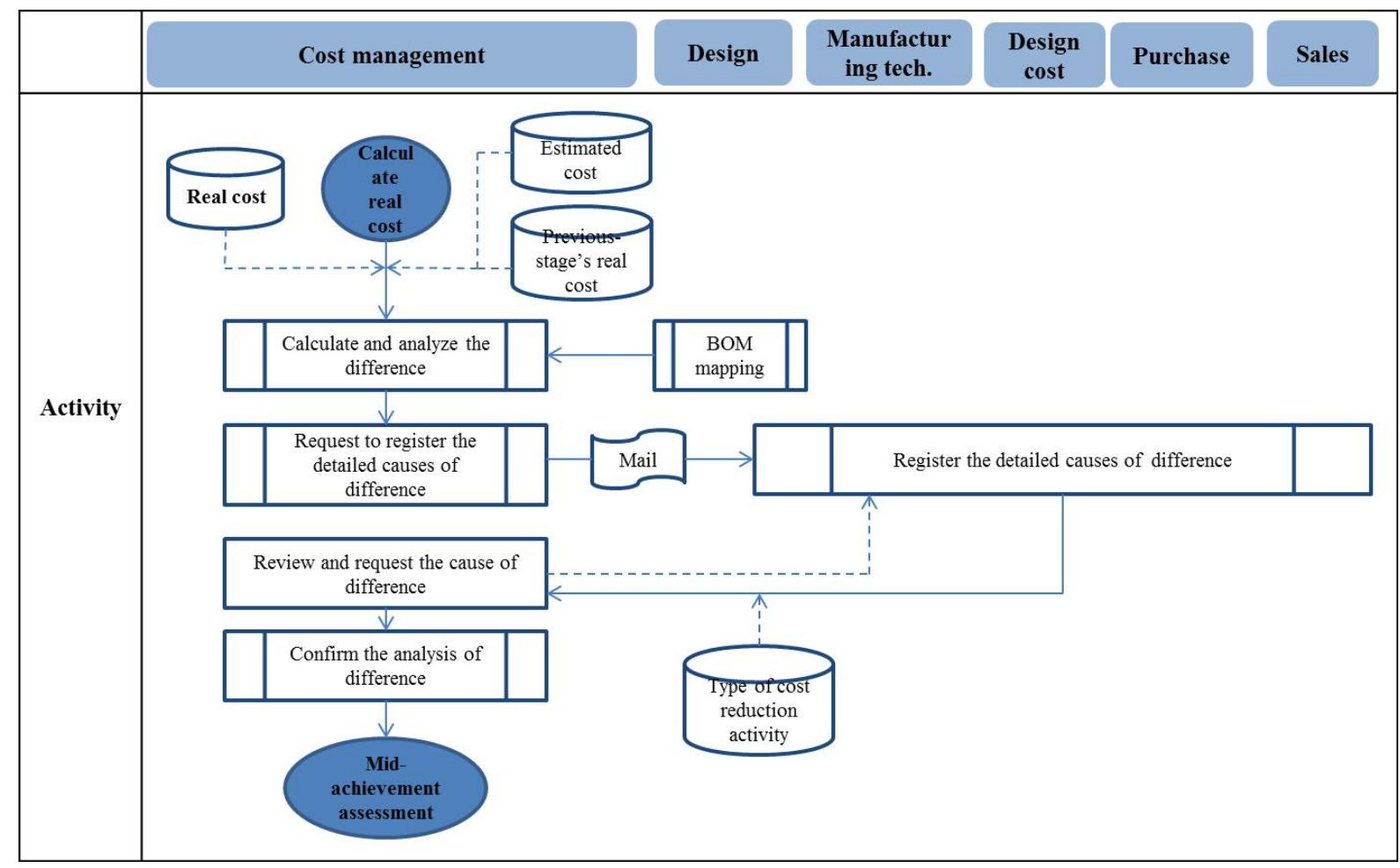

\subsubsection{Mid-Level Achievement Assessment}

The cost management division uses the detailed analysis results of the real cost difference and cost reduction types to calculate the reduced cost of the controllable factors identified among the cost changes. On the other hand, the reduced amount and the ratio of goal achievement by division (=reduced amount $\div$ target amount) are calculated and reported to each division with a view to providing feedback on the achievement assessment results. Each division compares the registered factors with the calculated reduced amount and ratio of goal achievement. Meanwhile, the cost management division calculates the target amount which has not been achieved in order to use it in the redistribution of the goals among divisions. The above process is summarized in Figure 18. 
Figure 18. Mid-level achievement assessment

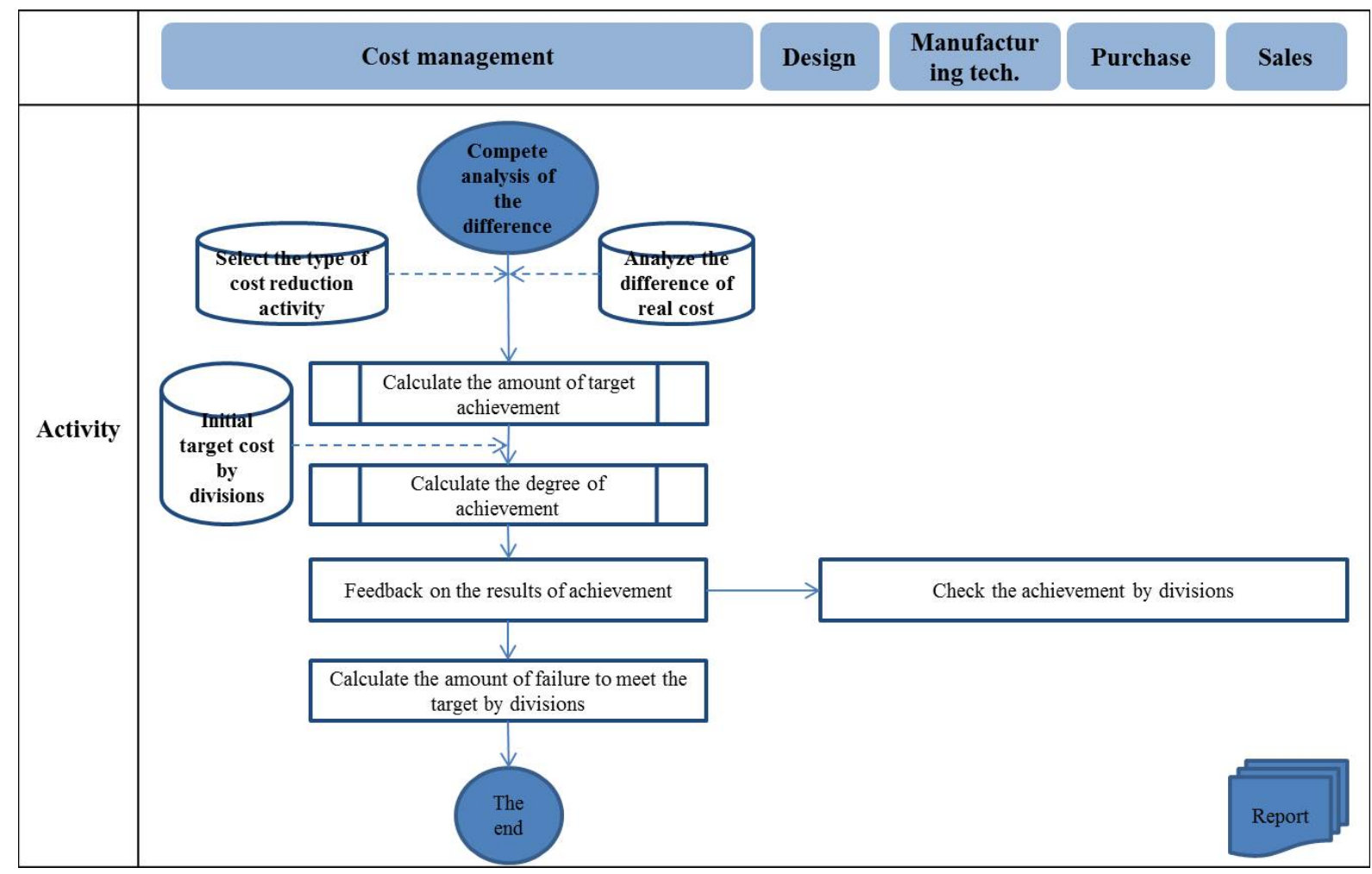

\subsubsection{Target Re-Distribution}

The cost management division uses the results of the analysis of the real cost difference to determine whether to redistribute according to the difference factors, except for the parts that cannot be controlled. The re-distributed amount is classified as attributable or unavailable according to the division. Attributable items are directly imposed to the relevant division and common items are proportionally divided according to the reduction ratio from the initial goal establishment. After the re-distributed amount is calculated for each sector, the target re-distribution amount is checked and the reduction plans are re-registered. The above process is summarized in Figure 19. 
Figure 19. Target Re-Distribution

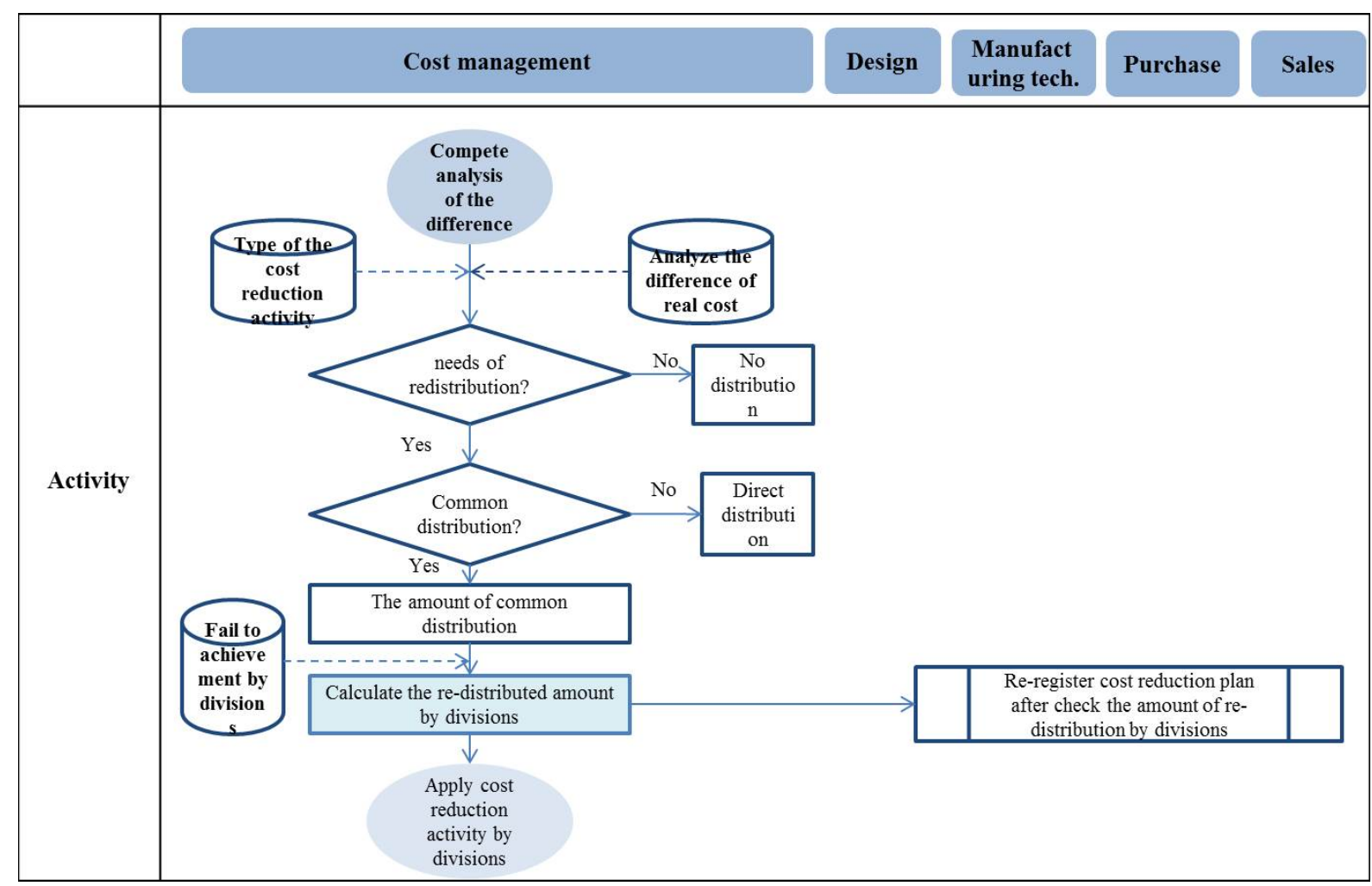

\subsubsection{Assessment of Performance Achievement}

The cost management division compares the actual cost with the target cost of the product. Furthermore, the purchasing, design, manufacturing technology, and sales divisions are requested to register the detailed causes and activities explaining the difference in the real cost. Afterward, each division registers the detailed activities that triggered the difference and selects the type of previously-defined cost reduction activity.

The cost management division for its part checks whether the registered content is reasonable and requests the reregistration of inappropriate content. After confirming the specific activities that triggered the cost differences recorded for each division, the degree of achievement (=reduced amount $\div$ target amount) is calculated and reported to each division as feedback on the causes of failure to meet the targets. The above process is summarized in Figure 20. 
Figure 20. Assessment of performance achievement

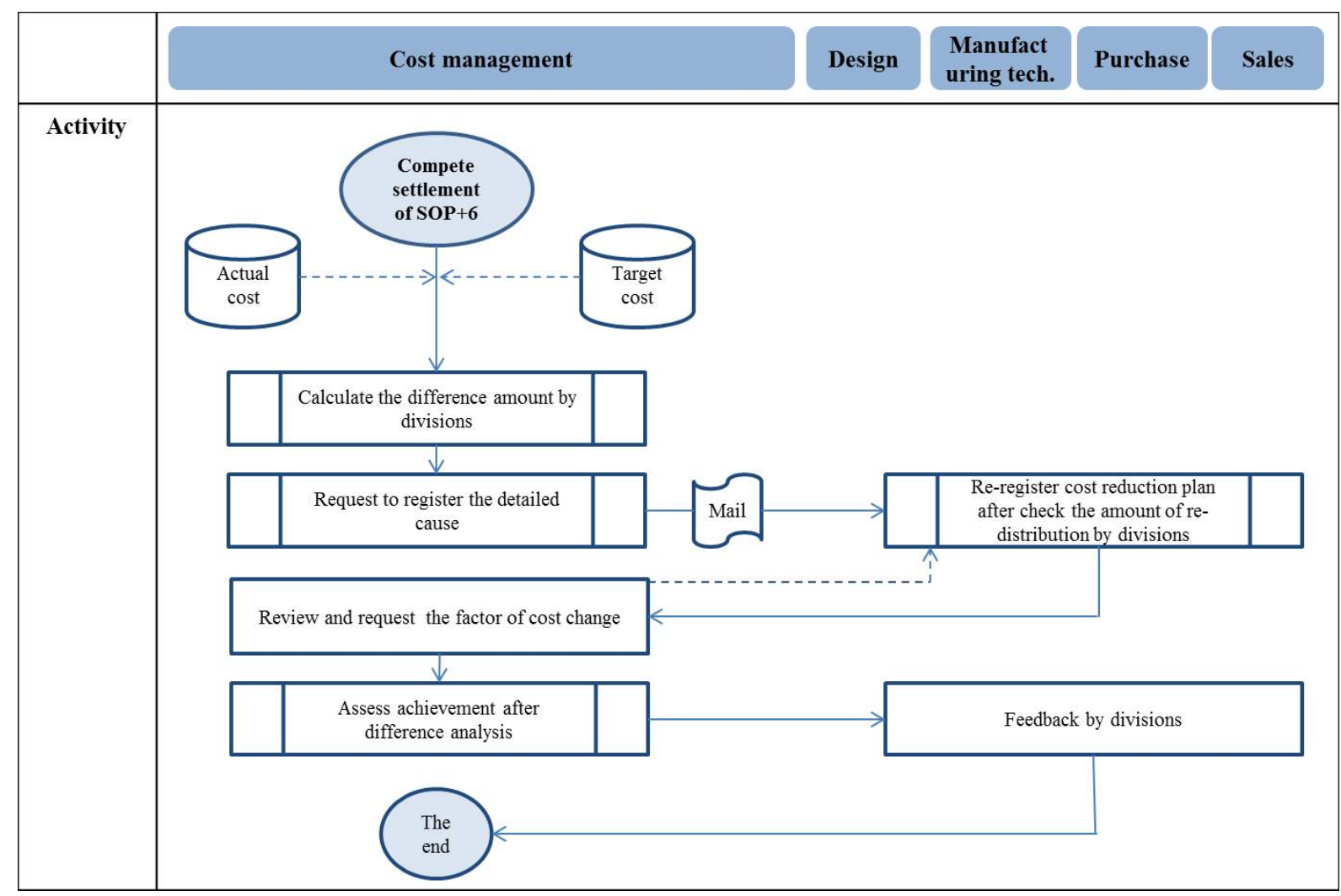

\subsection{Practical Implications}

Many companies follow traditional management strategies rather than adopting a scientific and specialized management method based on accurate cost information. However, in the recently intensified business environment, the barriers protecting domestic companies have been rapidly destroyed by global market dynamics, leaving firms exposed to competitive international market situations. To acquire a competitive edge in the midst of such intense competition, companies are making plans in relation to various aspects, cost reduction being one of their major goals. Furthermore, the customers of the company surveyed in this study have been continuously pressuring the firm to lower its product prices and to expand the scope of its cost-control under the dominant market structure of A \& B Motor. Therefore, the company in our case study recognized the need for change to enhance its cost competitiveness in the face of intensified competition from global companies and the expansion of cheap production bases such as in China. In addition, various OEM business opportunities were expanded after the company enlarged its size through continuous business expansion and global market entry. This in turn called for consolidation of the firm's external risk management and internal cost management. Under these circumstances, it is expected that this study will provide the following practical contributions.

First, as processing precision has been improved by the automation of the manufacturing environment, companies are now facing limitations in reducing their processing costs. In this sense, most manufacturers - including A Company. - must consider the material costs which account for a large part of the product costs and take active measures to respond to the unit cost level set in reference to the customer-requested sales price. Thus, to achieve the target cost, it is important to make changes by implementing an innovative cost management system.

Second, the original purpose of the target cost system is to expand the objects of cost reduction to the R\&D, design, and planning \& strategy stages which take place on the production site prior to the manufacturing phase along with 
the JIT (just in time) method. The system must be developed in consideration of the management reality and business conditions of Korean corporations in addition to Japanese manufacturers.

Third, Korean companies have recently begun to recognize that to manage product costs, it is important to carry out cost-cutting activities at the developmental design stage. However, this importance has been merely understood in its ideological dimension, with very few precedent studies on the specific techniques or methods for planning and improving costs at the product planning and design stages. Therefore, as a case study on an innovative target cost management system, this study is significant in that it closely examines how the company of the case study constructed its target cost management system.

Lastly, there exist various types of cost management systems according to country and company. However, the target management system recently created by the case company of this study can be extensively used by other companies. This is because in order for companies to survive amid fierce competition, they must inevitably expand their cost-cutting from the top stages of production, i.e. the R\&D and design, to the planning and strategy. Thus, this case study can be used to build a customized target cost management system in consideration of the firm's unique business environment, which will in turn boost the firms' global competitiveness.

\section{DISCUSSION}

The purpose of this study was to examine the case of the target cost management system recently introduced by A Company, with a view to helping the companies considering the adoption of a target cost management system to better understand and effectively apply the system at work. This chapter mentions the various problems that may arise in the construction and application of the target cost management system.

\subsection{Establishment of Guidelines for Target Profit Rate}

There are two alternatives for the establishment of guidelines for the target profit ratio. The first method is the calculation of the target profit ratio based on the NPV (net present value). In other words, the total income statement of the project period is used to analyze the order validity, through which the board of directors then establishes the guidelines for the target profit ratio. As this method is based on a project validity analysis, it indirectly reflects the will of the management. Besides, motivation is high as the agreed goal of the management is imposed on individual projects. Furthermore, as the risks, profitability, and strategic factors have already been analyzed in the review of the project validity, individual characteristics such as customer, country, and product family, are reflected in the target profit ratio.

The second method involves calculating the target profit ratio by reflecting the will of the management. Thus, the project is segmented into project/product/customer units and the will of the CEO or CFO with regard to the target profit ratio is applied to regularly manage the target profit ratio based on the past performance of the business plan. Although this method directly reflects the will of the management regarding the target profit ratio, it makes it difficult to reflect the individual characteristics of the customers, nations and product families in the target profit ratio. Besides, as the target profit ratio is determined by the management, the company members are not highly motivated to cut back on costs.

\subsection{Management of Reduction Goal at Developmental Stage}

The following two methods can be used to manage the developmental-stage reduction goals. The first method is to impose the reduction goal at the developmental stage. Through this method, the reduction goal is imposed at the development stage and the degree of achievement is subsequently managed. As the effects of cost-cutting are reflected in the sales price, the profits gained during product manufacturing are reflected in the adjusted sales price. This method is closely connected with the purpose for introducing the target cost management system and it helps the company not only to gain profits, but also to secure a basis for profit creation through cost competitiveness.

The second method is to carry out cost-cutting measures at the production stage. This method excludes the costcutting goals in the development stages and focuses on production-stage reduction goals. Profits are evidenced when 
the initial sales price is reflected in the first sales price at the production stage. Excess earnings can be obtained until the adjusted sales price is applied, but limitations arise from the postponed potential of the cost reduction.

\subsection{Period of Information Disclosure Per Division}

The following two methods can be used to determine the period of information disclosure per division. The first method is to share the cost information after calculating the new material cost. In this method, the estimated costs for each division are collected and reviewed by the cost management division and the related departments will hold discussions regarding the cost difference. This method facilitates accurate task division through cost sharing after the task implementation.

The second method is to share the information and cooperate from the start of the task implementation. In this method, the information regarding the calculated cost of the new material is instantaneously shared and continued cooperation is maintained between the design and purchasing divisions. In this scenario, as the cost management division is included in the cost negotiations after the cost estimation, work efficiency is improved through information sharing.

\subsection{Schedule for Sharing and Writing Material Cost Records}

The following two methods can be used to establish the schedule for sharing and writing the material cost records. In the first method, the design costing and purchasing divisions share the estimated costs. The design costing division calculates the costs of the new materials $\left(4^{\text {th }}\right.$ day) and the purchasing department will take note of their data to calculate the estimated costs $\left(5^{\text {th }}\right.$ day). The cost management division will refer to the information provided by the two divisions in order to review and negotiate a final estimated price. This method allows the company to calculate the estimated material cost by using optimal information from each division while providing evidence for the calculated cost to cooperating firms. Furthermore, it improves work efficiency and prevents redundancy through inter-departmental information sharing.

The second method is for the design cost division and purchasing division to independently estimate the cost. In this method, the design costing and purchasing divisions will calculate the costs of the new materials $\left(5^{\text {th }}\right.$ day) separately. The cost management division will review and negotiate on the basis of the cost information provided by the two divisions. This method allows each division to carry out its duties independently and provides the same timeframe for task implementation, promoting fairness between departments. Moreover, the cost management division can examine the cost provided by each division.

\section{CONCLUSION}

The above chapters examined the way the case study company constructed its target cost management system. The case company in this study, A Company is known as an automobile maker with a large, relatively well-organized cost management system. The information verified in this case study can be summarized as follows. First, the case company attempted to build a target cost management system by focusing on 5 items: estimation-stage BOM management, material cost calculation, assessment of the reduction goal achievement, standards for target profit rate, and distribution of the reduction goal among divisions. For these 5 items, the case company considered the following to be the main elements of the target cost management system: (1)a system for calculating the estimated costs and analyzing profitability and (2) a system for imposing and managing the target cost.

First, the following 7 items were considered important in relation to the system for calculating the estimated costs and analyzing the profitability: composition of an RFQ registration and order consultative group, selection of products for estimated cost calculations, writing of the estimated BOM and calculation of the component prices, review and calculation of the new personnel and investment costs, calculation of the estimate standard price, profitability analysis, and post-order management. Next, the following 8 items were extracted in relation to the system for imposing and managing the target cost: selection of the target cost subject, selection of the target profit rate, distribution of the target reduction plans among divisions, calculation of the real cost by stage, difference 
analysis of the real cost, mid-level achievement assessment, target re-distribution, and assessment of the performance achievement.

This study also mentioned the problems that may arise during the construction and application of the target cost management system in relation to the establishment of guidelines for the target profit rate, management of the reduction goal at the development stage, period of information disclosure according to the division, and schedules for sharing and writing the material cost records. These issues must be solved by the individual firms planning to build a target cost management system.

The purpose of this study was to present the case of a company that had recently adopted a target cost management system in order to help the firms considering the adoption of a target cost management system to better understand and effectively apply the system at work. In light of this, the study is expected to contribute to businesses in the following ways.

First, as the automation of the manufacturing environment now restricts companies from reducing their processing costs, most manufacturers are in need of a cost management system to help them cut back on the material costs that account for a large part of the product costs. The target cost management model expands cost-cutting to the R\&D, design, planning and strategy stages preceding production. As such, it can play an essential role in increasing corporate competitiveness through cost reduction. Second, the target cost management model will be effective in helping firms to enhance their cost competitiveness if it is developed in consideration of the management techniques developed by Japanese manufacturers and of the management reality and business conditions of Korean corporations along with the JIT (just in time) method. Third, Korean companies have recently begun to recognize that in order to manage product costs, it is important to carry out cost-cutting activities at the developmental and design stages.

However, this importance has so far been merely understood in its ideological sense, with very little focus few on the specific techniques or methods for planning and improving costs at the product planning and design stages in previous studies. Therefore, this study is significant in presenting a specific and concrete method for constructing a target cost management system which can be extensively adopted by various types of firms.

\section{AUTHOR BIOGRAPHIES}

Dr. Sung Jin Park is an assistant professor at the department of business administration, Sungshin Women's University. His research focuses on financial accounting, auditing, management information system, management $\&$ cost accounting, taxation. (1st author)

Dr. Woo Jin Park is an assistant professor at the college of Government and Business, Yonsei University. His research focuses on International Financial Reporting Standards(IFRS), Continuous Auditing Systems, R\&D investment in IT industry, strategic management information systems, project management, international taxation and accounting. (corresponding author)

Sohee Woo is an assistant professor at Woosong University in Korea. Research interests included auditing, corporate governance, financial management and capital market in accounting. (co-author)

\section{REFERENCES}

Berliner, C., Brimson, J. A. (1998). Cost management for today's advanced manufacturing. Harvard Business School Press. Blanchard, B. S. (1978). Design and manage to life cycle cost. Chesterland, OH: matrix press.

Choi, H. J., 1996. Target costing as a strategic cost management. Journal of Korea Commercial Education, 1(1), $225-266$.

Cooper, R. (1995). When lean enterprise collide: competing through confrontation. Boston, MA: Harvard Business School Press.

Cooper, R., Slagmulder R. (2000). Develop profitable new products with target costing. IEEE Engineering Management Review, 28(1), 79-88.

Foster, G., Sjoblom, L. (1996). Quality improvement drivers in the electronics industry. Journal of Management Accounting Research, 8, 55-86. 
Ibusuki, U., Kaminski P. C. (2007). Product development process with focus on value engineering and target-costing: a case study in an automotive company. International Journal of Production Economics, 105, 459-474.

Kato, Y. (1993). Target costing support systems: lesions from leading Japanese companies. Journal of Management Accounting Research, 4(2), 33-47.

Lee, C. S., Kim, W. H. (2003). Impact of participation levels in the budgeting process and performance evaluation methods on achieving goal of target costing. Korea Accounting Review, 28(2), 25-47.

Monden, Y., Hamada, K. (1991). Target costing and Kaizen costing in Japanese automobile companies. Journal of Management Accounting Research, 3(3), 16-34.

Noreen, E. W., Burgstahler, D., 1997. Full-cost pricing and the illusion of satisficing. Journal of Management Accounting Research, 9, 239-263.

Park, M. H., Hae, J. H. (1999). Target costing as a strategic product price decision. Korea Accounting Information Review, 4 , $123-138$.

Sakurai, M. (1989). Target costing and how to use it. Journal of cost Management, 3(2), 39-50.

Shim, E., Sudit, E. F., 1995. How manufacturers price productions. Journal of Management Accounting Research, 5, $504-521$.

Song, K. H. (2000). Cost allocation strategic using target costing. Korea Accounting Review, 5(1), 181-195.

Yazdifar, H., Askarany, D. (2010). A comparative study of the adoption and implementation of target costing in UK, Australia and New Zealand. International Journal of Production Economics, 135, 382-392.

Yook, K. H. (1994). Target costing in Korea automobile company. Journal of Korea East-South Management, 9, 1-26.

Zengin, Y., Ada, E. (2010). Cost management through product design: target costing approach. International Journal of Production Research, 45(19), 5593-5611. 


\section{NOTES}

